\title{
Rekreacja we współczesnych założeniach architektoniczno- -urbanistycznych
}

\section{Recreation in contemporary architectural and urban layouts}

\begin{abstract}
Streszczenie
Niniejszy artykuł został poświęcony zagadnieniom związanym z rekreacją i wypoczynkiem we współczesnych założeniach architektoniczno-urbanistycznych. W prezentowanych przestrzeniach miejskich i pozamiejskich istotną rolę pełni ekologiczna, a zarazem ekspresyjna forma architektoniczna, która powiązana ze środowiskiem przyrodniczym, kształtuje atrakcyjną przestrzeń rekreacyjną.

Kompozycja różnorodnie kształtowanych założeń architektonicznych i urbanistycznych, nawiązuje do krajobrazu miejskiego lub naturalnego, w którym rekreacja i wypoczynek zajmują nadrzędne miejsce, tworząc optymalne i wymarzone miejsce dla człowieka.
\end{abstract}

\begin{abstract}
This article has been devoted to matters associated with rest and recreation in contemporary architectural and urban layouts. Eco-friendly and expressive architectural form, which, in combination with the natural environment, creates an attractive recreational space, plays an essential role in the urban and non-urban spaces that have been presented.

The composition of the diversely shaped architectural and urban complexes features references to either the urban or the natural landscape, one in which rest and recreation take centre stage, creating an optimal and highly desirable place for man.
\end{abstract}

Słowa kluczowe: rekreacja, wypoczynek, założenia architektoniczno-urbanistyczne, przestrzeń rekreacji Keywords: recreation, rest, architectural and urban layouts, recreational space

\section{WPROWADZENIE}

Funkcja rekreacji i wypoczynku jest często nie doceniana we współcześnie kształtowanych przestrzeniach miejskich, pomimo iż jest niezbędna do życia człowieka. W triadzie dom - praca - wypoczynek, wypoczynek odgrywa niepoślednią rolę. W ostatnich latach, w dobie negatywnych skutków dla życia człowieka i przyrody, jakie niesie zanieczyszczenie powietrza i ocieplenie klimatyczne naszego globu, problem rekreacji staje się priorytetem. W założeniach architektonicznych i urbanistycznych, kreacje funkcjonalno - przestrzenne winny być kształtowane $\mathrm{w}$ kontekście powiązań z terenami rekreacyjnymi oraz zielonym, przyrodniczym otoczeniem, zdrowego i przyjaznego środowiska miejskiego. Zagadnieniom związanym z rolą i znaczeniem rekreacji i wypoczynku w życiu człowieka na przykładzie prezentowanych kreacji przestrzennych został poświęcony niniejszy artykuł.

\section{ARCHITEKTURA REKREACJI}

Niniejszy artykuł dotyczy zagadnień związanych z kształtowaniem zdrowych i przyjaznych dla człowieka prze-

\section{INTRODUCTION}

The function of rest and recreation is often underappreciated in currently designed urban spaces, despite being necessary for man's life. In the home-work-rest triad, rest plays an essential role. In recent years, in a period of the negative impact that air pollution and global change exert on human life and nature itself, the problem of recreation has become a priority. Functional and spatial designs that are a part of architectural and urban complexes should be shaped in the context of linkages with recreational and green areas, natural surroundings and a healthy and friendly housing environment. This article has been devoted to the subject matter associated with the role and significance of rest and recreation in human life, on the example of the spatial designs presented herein.

\section{THE ARCHITECTURE OF RECREATION}

This article pertains to the subject matter associated with the shaping of urban spaces that are friendly to humans and their health and that exist within functional and spatial relationships within the man-nature-architecture system. 
strzeni miejskich, zachodzących w relacjach funkcjonalno-przestrzennych; człowiek - natura - architektura. Poniżej zostaly zaprezentowane cztery projekty rekreacyjnych załozen archicektoniczno-urbanistycznych, zlokalizowanych $\mathrm{w}$ różnorodnie ksztaltowanych przestrzeniach miejskich, ale zawsze powiązanych ze środowiskiem przyrodniczym oraz otoczeniem parkowo-wodnym. Zostały wyeksponowane niektóre aspekty dotyczące roli i znaczenia wypoczynku człowieka w miejscu zamieszkania.

\section{Rewitalizacja terenu przy parku miejskim w Ostrowcu} Świetokrzyskim 1 . Projekt 2019 [P.1 - P. 4]

Teren opracowania położony jest $w$ centrum miasta Ostrowiec Świętokrzyski. Od strony wschodniej graniczy z Parkiem Miejskim, od strony północno - wschodniej z Starym Miastem, a od południowej z nowoczesnym amthacra $Z$ dwóch stron; wschodniej i zachodniej teren jako kapieliska miejskie, ktore nie są wykorzystywan strefą usług Południowa cześć opracowywanego tere nu stanowi strefa przemystowa, pozostatość po tereHucie Ostrowiec. Omawiany teren mimo po Stare lokalizacii w centrum miasta i dogodnej dostepności komunikacja kołowa, autobusowa i kolejowa, a przede ksmunikacją kolowa, autobusową i kolejowa, a przede stopniu zaniedbany i zdegradowany.

Ideą projektu było zrewitalizowanie zdegradowanego terenu poprzemystowego, zlokalizowanego $\mathrm{w}$ centrum miasta, oraz stworzenie miejsca przyjaznego zarówno środowisku miejskiemu jak i mieszkańcom miasta. Celem projektu było funkcjonalno-przestrzenne oraz kompozycyjne powiązanie Parku Miejskiego wraz z amfiteatrem ze Starym Miastem, poprzez wprowadzenie dominującej funkcji rekreacyjnej parkowo-wodnej, stanowiącej atrakcyjną, wypoczynkową przestrzeń publiczna, dostępną dla mieszkańców miasta.

Przyjętym załozeniem projektu architektoniczno-urbanistycznego było stworzenie ośrodka edukacyjno-wy stawienniczego ze strefą rekreacyjna. Zaprojektowan zostały dwa budynki; budynek edukacyjny przeznaczony do ksztattowania i rozwoju zdolności artystycznych (rysunek, malarstwo, rzeźba etc.) oraz budynek wystawienniczy (z salą konferencyjna), w którym przewidzia-
no wystawy dzieł sztuki, a także organizowanie wystaw no wystawy dzieł sztuki, a takż
czasowych i innych wydarzeń.

czasowych i innych wydarzeń.
Kompozycję przestrzenną założenia stanowią dwie orKompozycje przestrzenną zalozenia stanowią dwie ordzińcem o uktadzie zieleni i mate wa w formie organicznej. Dachy budynków zostaty uksztattowane amfiteatralnie. Tworza je stopnie z zielenia, których przewidziano ruch pieszy. W niektórych stopniach zaprojektowane zostało doświetlenie wnętrz.

Lokalizacja zespołu architektoniczno-urbanistycznego została przyjeta w znacznym obniżeniu terenu, w zwiazku z tym powstała skarpa od strony północnej, która uksztaltowano $w$ formie stopni $z$ zielenia i betonowymi siedziskami. Po obu stronach założenia znajdują sie zbiorniki wodne, które połączono ciekiem wodnym. Komunikacja kołowa została ograniczona do minimum. Miejsca parkingowe zlokalizowano pod ziemią.
Below is a presentation of four designs of recreational ly-shaped urban spaces that are always connected with the natural wivironment and surroundings that feature parks and water. Certain aspects concerning the role an gnificance of rest in man's phace of residence have been highlighted in these designs.

The revitalisation of an area near the city park in Ostrowiec Swiętokrzyski'. Design from 2019 [P.1 - P. 4] The site of the project is located in the centre of the tow the City Park, from the north-east on the Old Town, while
the from the south, on a modern amphitheatre. The area is surrounded from the east and west by water reservoirs that are used as city bathing spots. Immediately to the west of the site is a service zone. The southern part of the site is occupied by an industrial zone-the remnants of the Old Ostrowiec Metallurgy Plant. The site, despite its attractive location in the city centre, is suitably accessible by car, bus and rail, but most importantly-by alkable paths but is, unfortunately, largely in a state of eglect and decay

The idea behind the design was to revitalise a decayed create a place that would be friendly both to the us to environment and the city's residents. The goal of the design was to functionally, spatially and compositiona ly link the City Park and the amphitheatre with the Old Town by introducing a park and water-based recreational function, which would form an attractive recreationa public space, accessible to the city's residents.

The assumption that was adopted for the architectura and urban design was to create an education and exhibition centre with a recreational zone. Two building were designed: an educational building meant to shape and facilitate the development of artistic talent (drawing painting, sculpture, etc.), as well as an exhibition building (with a conference hall), in which artwork exhibitions are to take place, as well as for the organising of temporary Thibitions and other events.

The spatial composition of the complex is comprised of hat features a lacut of is likewise organic. The roofs of the buildings have bee shaped into amphitheatres. They are formed by been with greenery meant for pedestrian traffic. Some steps with greenery meant for pedestrian
feature additional insolation openings.

The placement of the architectural and urban complex was chosen in a spot that is significantly lower than its surrounding terrain, which produces an escarpment to the north that has been designed in to a stepped form, with greenery and concrete seating. The complex is surrounded on both sides by water bodies that were connected with a waterway

Vehicular circulation was restricted to the necessary minimum. Parking spots were placed underground. A large amount of greenery was proposed in the intering natural sunlight into the interiors, also make it possble for them to blend with the external area of greenery. The main materials used in the buildings are concrete and glass, with elements that are coloured black.
W obydwu budynkach we wnętrzach zaproponowano duzą ilośc zieleni. szklen, wprowadzając naturalne swiatło słoneczne, jednoczesnie umoźliwiają przenikanie wnętrza z otaczaącym zewnętrznym terenem zieleni. Glównymi zastosowanymi w budynkach materiałami jest beton oraz szkło zelementami czern

"....Całość projektu spaja zieleń, która jest elementem dominującym oraz przewodnim. Organiczne formy budynków wyrastaja z ziemi i stapiają się z krajobrazem Parku Miejskiego. Jest to miejsce przeznaczone do kontemplacji natury i sztuki, a jednocześnie rekreacji..." Miejsce to ma stać się zarówno przestrzenią integraci
mieszkańców miasta, jak i integracji człowieka i natury. Rewitalizowany teren tworzy całość z Parkiem Miejskim pod względem rozwiązań funkcjonalno-przestrzennych oraz krajobrazowych. Dominuje funkcja rekreacyjna i wypoczynku z wiodącą rola powiazzań pieszych, harmonijnie powiazana ze środ piskiem przyrodniczym w centralnej miejskiej przestrzeni miasta. Oryginalna a zarazem ekspresyina ekologiczna forma architekto nicza, wkomp nia wodno-parkowego, stanowi atrakcyine centrum rekreacji.

Pod względem kompozycyjnym i estetycznym projekt cechuje wysoka jakość przyjetych rozwiazzań funkcjona no-przestrzennych oraz krajobrazowych.

\section{Centrum edukacji geologiczno-przyrodniczej przy} Pustyni Beedowskiej². Projekt 2018 [P.5 - P.7]

Projekt dotyczy Centrum edukacji geologiczno-przyrodniczej. Obiekt został zlokalizowany we wschodniej cześci Wyżyny Śląskiej, w miejscowości Chechło, w gminie Klucze i powiecie Olkusz, w województwie Małopolskim, przy punkcie widkowym Dąbrówka, z ktorego mozna podziwiac rozlegly krajobraz Pustyni Blędowskiej, potocznie zwanej „polską Saharą". Liczne walory przyrodnicze, krajobrazowe oraz geologiczne mialy decydujący wpływ na wybor tematu i lokalizację obiektu, łącząceg w sobie turystykę, wiedzę oraz rekreację. Teren opracowania jest położony przy północnej granicy Pustyn Błędowskiej, pomiędzy pustynią, lasem oraz terenam rolnymi. W Miejscowym Planie Zagospodarowania Prze strzennego teren jest przeznaczony pod budynek o funkcji turystycznej i rekreacyjnej. W sassiedztwie terenu nie ma zadnej zabudowy, najblższe budynki są położon

adzona ze środka działk

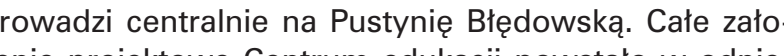
wstało w odnie-

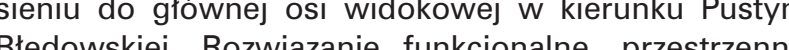
oraz kompozycyine architektoniczno-urbanistyczne jest osiowe oraz symetryczne. Budynek posiada horyzontalna bryłe z zielonym dachem użytkowym, z piaskiem na jego powierzchni i pustynnymi roślinami. Pełni on funkcję obszernej platformy widokowej z kawiarnia, z które można podziwiać rozległy krajobraz Pustyni Błędowskiej. Taras widokowy jest także dostępny bezpośrednio $\mathrm{z}$ terenu, symetrycznymi schodami wkomponowanym w bryłę budynku.
"...The entirety of the design is linked by greenery, which is the dominant and overarching element. The organic forms of buildings emerge from the ground and blen in with the landscape of the Cly Park. It is a place mean for the contemplation of nature and the arts, as well as a pecto bot a place of the integration of city residents, as well as th The ation of man and nature.

Pith tions. The function of rest and recreation is dominant, along with the prominent role of pedestrian linkages, harmoniously linked with the natural environment, withexpressive eco-friendly architectural form, incorporated into the natural surroundings of the wider park and water layout, constitutes an attractive centre of recreation.

In compositional and aesthetic terms, the design is characterised by the high quality of its functional, spatial and
landscape solutions.

The geological and wildlife education centre Będów Desert ${ }^{2}$. Design from 2018 [P.5 - P.7]

The project is a design of a geological and wildlife edpart of the Silesian Unland, in the locality of Chechto, the municipality of Klucze and the powiat of Okusz, in the Lesser Poland voivodship, near the Dabrówka obsevation spot, from which we can marvel at the extensive landscape of the Btędów Desert, colloquially called the "Polish Sahara". The numerous natural, landscape, an geological assets of the area determined the choice of the design subject and its site, which was meant to combine a tourist destination with knowledge and recreation. The site is located near the northern edge of the Blędow Desert, between the desert, the forest and farmland. The Land Development Plan for the area assigns it for a tourism and recreation building. There are no other building in the immediate vicinity, with the closest ones being located around $800 \mathrm{~m}$ away from the site's edge.

The primary visual axis leads straight from the heart of entire design assumption behind the educational. The was formulated with respect to the primary visual axis towards the Btedów Desert. The functional spatial and compositional layout is axial and symmetrical. The building has a horizontal massing with a usable green roof, its surface covered with sand and desert plants. It fulfils the role of a large observation platform with a coffee shop, extensive landscape of the Biędów Desert. The observation deck is also accessible directly from ground level, through symmetrical stairs incorporated into the building's massing.

The building was functionally and spatially linked with the surrounding greenery and the sandy desert terrain. The Centre, apart from its educational role, also has a tourist, cultural and recreational function. The Centre's central part of the building into thematic sections. The the representative section, which is a green forum with an internal winter garden, in which small exhibitions can be hosted. The following other sections were also arranged on the ground floor: the exhibition, multimedia 
Budynek został funkcjonalnie i przestrzennie powiązany z otaczająca go zielenią i pustynnym piaszczystym terenem

Projektowane Centrum oprócz roli edukacyjnej, pełn również funkcję turystyczną oraz kulturalną, a także rekreacyjna. Układ funkcjonalny Centrum został podzielony na tematyczne strefy. W centralnej części budynku, na parterze, została zlokalizowana strefa reprezentacyj$n a$, stanowiąca zielone forum $z$ wewnętrznym ogrodem zimowym, w którym mogą być eksponowane niewielkie wystawy. W parterze zostały wydzielone kolejne strefy ekspozycji, multimedialno-handlowa oraz gastronomicz na. Na piętrze znajduje się administracja i sale konferencyjne. Kolejna strefa to obszerna przestrzeń zielonego uzthi znaczaca role w rozwiazaniu archick rekreacyjna penistycznym Contrum dzieki zawartemu progra-urgastronomi, zielonej przestrzeni gówn wnetrznym ogrodem i zielonej przestrzeni tarasu widokowego, a także bezpośrednich powiazzań funkcjo nalnych i przestrzennych z rekreacyjny otoczeniem; wody, zieleni oraz piasków pustyni Błedowskiej [4] Surowość i naturalność architektury Centrum edukach została podkreślona przez zastosowanie; betonu architektonicznego jako materiału wykończeniowego elewacii dużych przeszkleń pionowych, a także doświetleń pozio mych podkreślających osiowość budynku i znaczeni funkcji pomieszczen, oraz u̇ycie naturalnego kamienia n posadzkach. Wejście główne, od strony pustyni zostało powiązane $z$ reprezentacyjnym placem z dwoma syme trycznymi zbiornikami wodnymi. Pomiędzy zbiornikami na centralnej osi założenia, zlokalizowano trakt pieszy prowadzący w stronę Pustyni Btędowskiej, podkreślają $w$ ten sposób rolę i znaczenie krajobrazu oraz srodowiska przyrodniczego w ksztaltowaniu przestrzeni rekreacynej. Przy drogach dojazdowych zlokalizowano parkingi. Założenie $w$ całości jest dostępne dla osób niepełnosprawnych, począwszy od dostosowania parkingów po zastosowanie odpowiednich wind w budynku.

Oryginalna i ekspresyjna forma architektoniczna, harmonijnie wkomponowana w otoczenie krajobrazu Pustyn Będowskiej, stanowi atrakcyjne centrum edukacji geologiczno-prysrodniczej. Architektura ekologiczna, powiazana integralnie $z$ otoczeniem, o użytkowym zielonym dachu pełniącym funkcję platformy widokowej, stwa
odpowiednie warunki dla aktywnego wypoczynku. Świętokrzyskie Centrum Nauki3. Projekt 2019 [P.8 - P.11]
Świętokrzyskie Centrum Nauki zlokalizowane zostato $w$ południowo-zachodniej części miasta Kielce przy ulicach Gwarków i Bernardyńskiej, u podnóża góry Karczówka, w sąsiedztwie rezerwatu krajobrazowego Karczówka z XVII wiecznym klasztorem na wzgórzu. Teren lokalizacji położony jest na obrzeżach miasta. W pobliżu znajdują się tereny mieszkaniowe oraz usługi oświaty, zdrowia i kościót. Teren jest dostępny komunikacją kołowa, ścieżkami rowerowymi, a także szlakami turystycznymi. Przedmiotowa lokalizacja znajduje się w obszarze znacznie zazielenion ka). Bezpośrednie sąsiedztwo terenu stanowi Ogród Botaniczny, będący znaczącym zbiorem gatunkowym and commerce, as well as the gastronomy section. The first floor houses the admin ence halls. The next section is the extensive space of the usable green roof and its coffee shop. The recreationa function plays a significant role in the architectural and urban design-related solutions of the Centre thanks to of the main forum with its internaly, the green space space of the observation deck, along with direct functional and spatial linkages with its recreational surroundings: water, greenery and the sands of the Btedów Desert [4] The austerity and natural character of the education decorative concrete as the facade finish, large vertical glazed surfaces, as well as horizontal skylights that underscore the axiality of the building and the significance of the function of its interiors, in addition to the use of natural stone on its floor surfaces. The main entrance from the side of the desert was tied with a representative square with two symmetrical water bodies. Between the ponds, on the complex's central axis, a pedestrian path leading towards the Bleçoow Desert was placed, highlighting the vironment in the shaping of recreationa space. Parking spaces were placed near the complex's

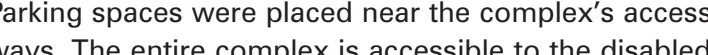
through the proper adaptation of the parking lot and the use of proper lifts in the building.

The original and expressive architectural form, harmoniously blended with the surroundings of the Btędów Desert's landscape, constitutes an attractive centre of geological and wildife education. Eco-firendy architecture, integrally linked with its surroundings, with a usacreates proper conditions for active recreation.

The Holy Cross Science Centre 3 . Design from 2019 [P.8 P.11]

The Holy Cross Science Centre was placed in the sth-western part of the city of Kielce, near Gwarków and Bernardyńska Street, at the foot of Mount Karczówka, in the vicinity of the Karczówka landscape preserve with its seventeenth-century hilltop monases and education and healthcare services, as well as a church. The site is accessible with through vehicular and bicycle circulation paths, as well as using tourist trails. The site is located in a significantly forested and overgrown area (the Karczowka preserve). The Botanical Garden, which includes a significant collection of small and tall plant species, is in the site's imme diate vicinity. The site possesses distinct landscape and church of the Pallottines on Mount Karczónka an xtensive view of the city's panorama and the neighbouring hills that surround

The overarching idea behind the design was to create was to create functional and eco-friendly solutions, as well as place for the local community and the general population to attractively spend their free time. The overarching criterion of shaping the centre was to take overo consideration the context of the place; its landscape, wildlife and te roślin niskich i wysokich. Teren lokalizacji posiada szcze gólne walory krajobrazow i widokowe o czym decydui kościót Pallotynów na górze Karczowka, rozlegly widok na panoramę miasta i okoliczn wzgórza otaczające miasto

Ideą przewodnią projektu było stworzenie uniwersalne przestrzeni aktywnej rekreacji, posiadającej funkcjona e i ekologizne rozwiazzania, oraz miejsca atrakcyjnego do spędzania wolnego czasu dla społeczności lokalne a także ponadlokalnej. Wiodącym kryterium ksztattowania Centrum było uwzględnienie kontekstu miejsca walorow krajobrazowych, przyrodniczych, uksztattowa nia terenu, a także zastosowanie lokalnych materiałów budowlanych. Prosta prostopadloscienna forma obieku zostala rozdzielona i rozsunęta, mialo to na celu wyeksKarcź́nce - panorama miasta. "Pekniecie" biegnace przez ́́rodek prostej bryty jest dominujacym akcentem catego założenia architektoniczno-urbanistycznego. Minimalistyczne w wyrazie i pozbawione otworów ściany budynku, sa przeciete szkleniem o dynamicznej i niere gularnej formie. Budynek podzielony na dwie bryły przez przeszklona przerwe, zawiera dwie czésci; wystawowa i laboratoryjna oraz konferencyjna i wykładowa Obi struktury przestrzenne zostały połaczone pod ziemia łącznikiem wystawowym. Całość założenia zawiera kilk stref funkcjonalnych takich jak; wystawiennicza, wykła dowa i konferencyina, laboratoryina, gastron administracyjna oraz zielony dach użytkowy [5].

Obie części założenia architektoniczno-urbanistycznego zostały integralnie powiązane atrakcyjnie ukształtowanym zagospodarowaniem terenu z ogrodem i zbiornikiem retencyjnym, elementami małej architektury oraz krajobrazu naturalnego. Oryginalna i ekologiczna archiny dach o prowadzącą z whętrza budynku na zielony dach, oraz "deszczowe atrium" stwarzają charakterystyczny klimat, adekwatny do kontekstu miejsca.

Kompozycja zespołu nawiązuje do krajobrazu miasta o szczegölnych walorach krajobrazowych, w którym rekreacja i wypoczynek zajmuje bardzo ważne miejsce.

Ośrodek sportu i rekreacji w Kielcach ${ }^{4}$. Projekt 2019 P.12 - P.14

Ośrodek sportu i rekreacji został zlokalizowany w Kielcach przy ulicy Zagnańskiej, wśród terenów mieszkaniowych oraz w bliskim sassiedztwie Zalewu Kieleckiego, pziny kiecki riag rekricy, wzdhz korej przeblega kowy i rowerowy; który wraz z towarzysząca ziecnia niejednokrotnie parkowa przebiega przez cate centrum miasta Kielce. Wśród bujnej roślinności otaczajacej Za lew Kielecki znajduje sie rozbudowana infrastruktura wypoczynkowa, wyposażona w ścieżki rowerowe, spa cerowe miejsca ćwiczeń na świeżym powietrzu i spafunkcje, stwarzajace możliwości aktywnego wypoczynku mieszkańcom miasta.

....Publiczne centra sportowe spełniaja ważna funkcję w społecznościach, służąc jako miejsce do kontaktu z innymi ludźmi oraz udziału w sporcie. Połaczenie sportu z rekreacja pozytywnie wpływa na aktywnośc psychofizyczną człowieka, która jest bardzo ważna nie rain-related assets, as well as the use of locally available building materials. The simple cuboid massing was separated and set apart, which was meant to highlight and accentuate the visual axis between the monastery on Mount Karczówka and the panorama of the city. The "split" through the middle of the simple massing is the dominant accent of the entire architectural and urban pression and devoid of openings-are cut through with with a dynamic and irregularly-shaped fhe building divided into two massings by the glazed gap, includes two parts: an exhibition and laboratory section and a conference and lecture section. Both spatial structures were connected with a corridor for hosting exhibitions underground. The entire complex features the following functional zones: the exhibition zone, the lecture and conference zone, the laboratory the usable green roof [5].

Both sections of the architectural and urban complex were integrally linked with attractively shaped site development, featuring a garden and water reservoir, stree furniture elements and those of the natural landscape. The original and eco-friendly architecture, with a ramp and the "rainy atrium", create a distinct a tmo gren roof equate to the context of the site. The composition of the complex features references to the landscape of the city with distinct landscape assets, in which recreation and rest occupy a vital position.

Sports and recreation centre in Kielce. Design from 2019 [P.12 - P.14]

The sports and recreation centre was placed in Kielce near Zagnanska Street, within a residential area and in close proximity to the artificial Kielce Lake, built along the Silnica River, along which there runs an important recreation walking and bicycle path sequence. The sequence, along with its accompanying greenery, which includes sever parts, ed by the lush greenery that surrounds Kielce Lake there with bicycle and walking paths, places for open-air physical activity and other functions that create opportunities for active rest for the residents of the city.

Public sports centres fulfil an important function in communities, serving as a place of interpersonal contact sorts. The combining of sport with recreation positively affects man's psychophysical activity, which is very important not only during the development and growth of children, but also aids adults and seniors in overcoming everyday problems and psychosomatic illnesses. This is why it is important to promote an active and healthy lifestyle. The conceptual design that is being presented is meant to satisfy current human needs, while the architecture, greenery and water ar meant to create a friendly space..." [3]

The proposed functional and spatial solution originally the newly-designed eco-friendly urban environment.

The architectural design of the sports and recreation centre, adapted to contemporary needs and requirements 
tylko w czasie rozwoju i dorastania dzieci, ale również pomaga osobom doroslym i starszym wzmaganiu sie z codziennymi problemami, jak i chorobami o podłoż psychosomatycznym. Dlatego tak wazne jest promowanie aktywnego i zdrowego trybu zycia. Prezentowan koncepcja ma odpowiadac na wspolczesne potrzeby człowieka, a architektura i zieleń z wodą ma stanowic przyjazną przestrzeń..." [3]

Proponowane rozwiązanie funkcjonalno-przestrzenne w sposób oryginalny pokazuje symbiozę pomiędzy istniejącym naturalnym otoczeniem, a kreowanym ekologicznym środowiskiem miejskim.

Kreacja architektoniczna Ośrodka sportu i rekreacji, dostosowanego do współczesnych wymogów i potrzeb zwiazzanych ze spędzaniem wolnego czasu, stwarza cii, powiqzane z Kieleckim Zalewem. Pod wzgledem kompozycyinym architektura tworzy nowy konters pozpayayny na podiesierie komfor nu w k kodowisk miejskim kształtowanym przez człowieka.

Układ przestrzenny ośrodka polega na kompozycii trzech modularnych, powiazanych ze soba bryt, zwiazanych rów nież z podziatem funkcjonalnym. Budynek posiada użytkowe zielone dachy które wpisuiąc sie w charakterystyczny klimat miejsca, jednocześnie powiekszzaja powierzchnie biologicznie czynną. Zastosowanie takich materiatów jak drewno, beton i kamień sprawia, że ośrodek ekologicz nie" wpisuje sie w otoczenie. Ośrodek dzieli sie na trzy części; hotel z restauracia, hala basenowa i hala sportowa. Każda z części posiada osobne wejście i funkcjonuje niezależnie od pozostałych. Część hotelowa zaprojektowana została w standardzie trzygwiazdkowym z atrium i salą restauracyjną dzieloną ruchomą scianą na dwie sale, konferencyjną i bankietowa. Hala basenowa z niecką basenowa o parametrach sportowych według przepisow FINA i batową dostosowaną do meczów pitki ręcznej, trzy boisk do squasha, siłownię, fitness, 2 sale lustrzane, salę do gry $w$ tenisa stołowego, salę do gry $w$ bilard i pomieszczeni dydaktyczne. Hala sportowa posiada w programie równiez widownię. Atrakcyjnie zaprojektowane, zielone otoczenie budynku zawiera program dostosowany do odpoczynku; bolska do badminona i zbionik wodny z siedziskami. Od strony drogi dojazdowej i głównych wejść do budynku zaprojektowano parkingi.

Całośc założenia architektoniczno-urbanistycznego Ośrodka sportu i rekreacji została wyrażnie podporząd miejskiej przejtrzeni, powizzanej harmo rekreacyjnej czeniem wypeczynkowe zen Zalewu Kieleckiego. Prostopadtościenny podzielony na trzy cześci budynek z oryginalnie zaprojektowanym zielonym dachem zosta zowiazany z atrakcyinie zagospodarowanym o zosta niem $i$ otwartym terenem wody i zieleni.

\section{Podsumowanie}

Jak pokazały wyżej zaprezentowane przykłady współczesnych założeń architektoniczno - urbanistycznych w różnych kontekstach; rewitalizowanych przestrze niach miejskich, krajobrazowych parkowo - wodnych założeniach funkcjonalno - przestrzennych, czy też miej- concerning the spending of free time, creates a space Kielce Lake. In terms of civersestion, its architecture . inprove comfort within the manmade urban environment.

The spatial scheme of the centre is based on a composition of three modular interlinked massings, which are Iso tied with functional zoning. The building has usable phere of the which, by blending into the distinct atmosically active surfaces. The use of materials like timber concrete and stone causes the centre to blend with it surroundings in an "eco-friendly" manner. The centre is divided into three parts: a hotel with a restaurant, an indoor swimming pool hall and a sports hall. Each of the sections has a separate entrance and functions separately from the others. The hotel section was designed to a three-star standard, with an atrium and restauran hall divided by a movable wall into two smaller spaces a conference and a banquet hall. The swimming poo hall has a swimming pool whose dimensions are compliant with FINA regulations, as well as a recreation pool. The sports hall includes. a sports hall adapted to club, two mirror spaces, a table tennis playing space, snooker and pool playing space, as well as teaching spaces. The sports hall also has an audience in its programme. The attractively designed green surroundings of the building include a programme that is adapted to rest and recreation: featuring badminton courts and a water body with seating. Parking spaces were designed from the side of the accessway and the main entrance to the building

The entrety of the architectural and urban complex of the sports and recreation centre was clearly subjected to the overarching idea of creating a green, recreation urban space, harmoniously linked with the surroundings of the recreational area of Kielce Lake. The cuboid building, divided into three parts, with an originally designed green roof, was linked with attractively deveand greenery.

\section{Conclusions}

As demonstrated by the examples of the contemporary architectural and urban complexes presented aboveeach located in a different context: revitalised urban spaces, landscape park and water functional and spatial complexes or urban spaces-the function of rest and recreation is dominant, along with walkability, functionally linked with the cultural and natural surroundings. A significant role is being played by architecture that is designed in an eco-friendly manner, with expressive, of ten organic forms and green roofs, in addition to park and water-based interiors that are optimally arrange hrough street funture and sports facilities.

列 for recreation. The composition of the complexes has moniously refers to the urban or natural landscape, in which rest and recreation occupy a prominent position, creating optimal and highly desired places for man. skich przestrzeniach, dominuje funkcja rekreacyjna i wypoczynku, a także piesza funkcjonalnie powiązana z kulturowym oraz naturalnym otoczeniem.

Znaczącą rolę odgrywa o ekspresyjnych, często organicznych formach z zielonymi dachami, oraz parkowo - wodne wnętrza optymalnie zagospoda

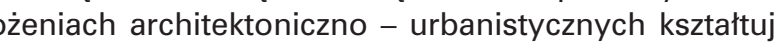
się miejsca wspólnie użytkowane, tworząc atrakcyjne przestrzenie dla wypoczynku. Kompozycja założen harmonijnie nawiązuje do krajobrazu miejskiego bądź naturalnego, w ktorym rekreaja imypocz mek zajmuje aquz nathe e miejsca dla człowiek

PRZYPISY

.Rewitalizacja terenu przy parku miejskim w Ostrowcu Świetokrzyskim". Au-
or: $\mathrm{mgr}$ inż. arch. Weronika Czerwonka. Projekt architektoniczno-urbanistyczny

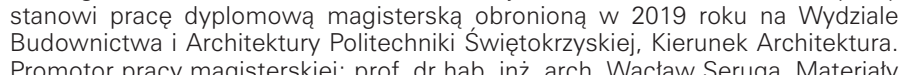
Promotor pracy magisterskiej: prof. dr hab. inzz. arch. Wactaw Seruga. Materialy
żródtowe: Archiwum Katedry Architektury i Urbanistyki Wydziatu Budownictwa

" "Centrum Edukacii geologiczno-przyrodniczej przy pustyni Btedowskiej". Autor:
mgr inż. arch. Adrianna Kus. Projekt archititektoniczno-urbanistyczny stanowi prace dyplomowa magisterska obroniona w 2018 roku na Wydziale Budownictwa
Architektury Politechniki Swietokrzyskiej. Kierunek Architektura. Promotor praa

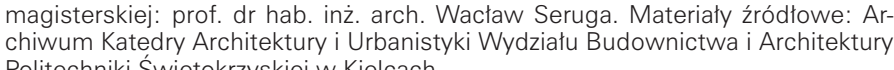
"Swiętokrzyskie Centrum Nauki". Autor: mgr inż. arch. Ewelina Metrycka. Projek

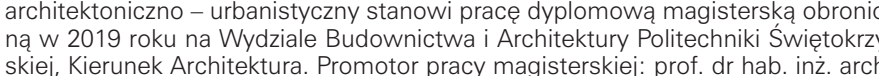

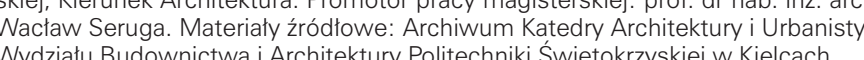
".Ośrodek sportu i rekreacii w Kielcach". Autor: inż. arch. Konrad Gębski. Proje

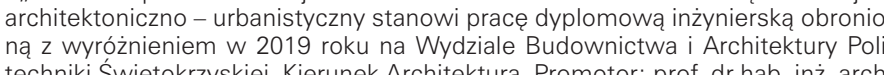
Wactaw Seruga. Materiały íródtowe: Archiwum Katedry Architektury i Urbanisty-
ki Wydzziatu Budownictwa i Architektury Politechniki Swiętok rzyskiej w Kielcach LITERATURA

[1] Czerwonka W. Rewitalizacja terenu przy parku miejskim w Ostrowcu Świe-
tokrzyski; praca dyplomowa magisterska wykonana na Wydziale Budownictwa Arrchitektury Politechniki S wietokkrzyskiej, Kielce 2019 r.
[2] Gehl J. Miasta dla ludzi; Wyd. 2010: Wydawnictwo w tlumaczeniu na jezyk

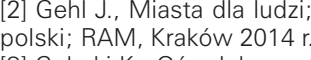

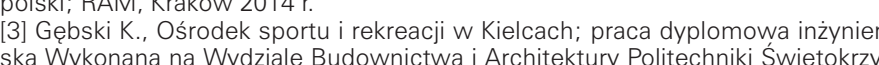
skiej, Kielce 2019 r.

[4] Kuś A., Centrum Edukacii geologiczno - przyrodniczej przy pustyni Btedow-
skiej; praca dyplomowa magisterska wykonana na Wydziale Budownictwa i

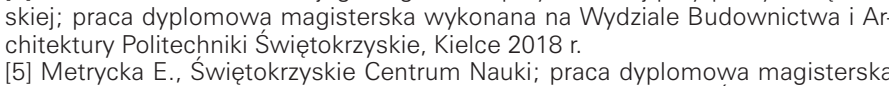

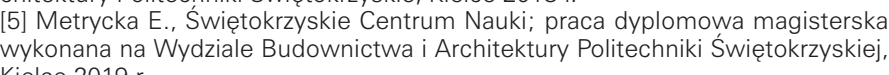

[6] Organic architecture inspired by nature, FKG 2010 r:
[7] Sergua W. A Architektura kontestust monografia Architektura 1/2014 Wydawni-

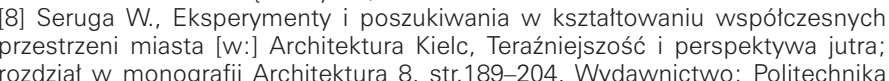
ozdziat w monografti Architektura 8, str.189-204, Wydawnictwo: Politechnik [9] Seruga W. Harmonia w przestrzeni miejskiej [W:] Architektura zharmonizowa
na w przestrzeni miasta; rozdziat w monografii Architektura 4, str. 9-20, Wydaw-

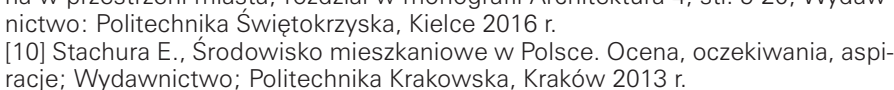

ENDNOTES

"Rewitalizacja terenu przy parku miejskim w Ostrowcu
Sumietokrzyskim". Author: mgr inż. arch. Weronika Czerwonka. The architectural and urban design is a Master's project Architecture of the Kielce University of Technologgy, Cout inz. arch. Wactaw Seruga. Source materials: Archives of the
Chair of Architecture and Town Planning of the Faculty of Civil Engineering and Architecture of the Kielce University "Centrum Edukacji geologiczno-przyrodniczej przy pustyni chedowskiej". Author: mgr inji. arch. Adrianna Kus. The
chitectural and urban design is a Master's project defendeded
in 2018 at the Faculty of Civil Engineering and Architectu-

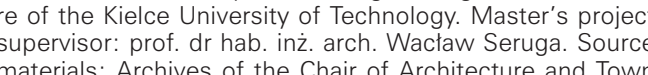
materials: Archives of the Chair of Architecture and Town
Planning of the Faculty of Civil Engineering and Architecture .S Swietokrzyskie Centrum Nauki". Author: mgr inż. arch.
Ewelina Metrycka. The architectural and urban design is Ewelina Metrycka. The architectural and urban design is
a Master's project defended in 2019 at the Faculty of $\mathrm{C}$ -
vil Engineering and Architecture of the Kielce University of Technology. Course: Architecture. Master's project su-
pervisor: prof. dr hab. inż. arch. Wactaw Seruga. Source marvisor: prof. dr hab. inz. arch. Wactaw Seruga. Source
materials: Archives of the Chair of Architecture and Town
Planning of the Faculty of Civil Engineering and Architecture of the Kielce University of Technology.
". Ośrodek sportu i rekreacij w Kielcach". Author: inz.
arch. Konrad Gebski. The architectural and urban design is arch. Konrad Gebski. The architectural and urban design is
a Master's project defended with honours in 2019 at the University of Technology. Master's project supervisor: prof.
dr hab. inż. arch. Wactaw Seruga. Source materials: Archidr hab. inż. arch. Wactaw Seruga. Source materials: Archi-
ves of the Chair of Architecture and Town Planning of the
Faculty of Civil Engineering and Architecture of the Kielce

BIBLIOGRAPHY

11] Czerrononka W. Rewitalizacja terenu przy parku miejskim
w Ostrowcu SWietorkryskim, tiploma project prepared at
the Faculty of Civil Engineering and Architecture of the Kiet the Faculty of Civili nngineering and Architecture of the Kiel[2] Gét J., Miasta dla ludzi; Wyd. 2010; in Polish; RAM.
Kraków 2014 [3] Gebski K.. Ośrodek sportu i rekreaciii w Kielcach; diplo-
ma project prepared at the Faculty of Civil Engineering and
Architecture of the Kielce University of Technology, Kielce 2019
$[$ [4] Kús A. Centrum Edukacji geologiczno-przyrodniczej przy

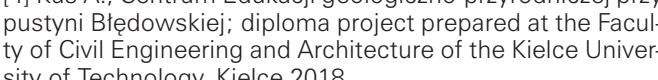
sity of Technology, Kielce 2018
$[5]$ Metrycka E Swietokrzskie project prepared at at the Faculty of Civil Engineering and [6] Organic architecture inspired by nature, FKG 2010 [7] Seruga W. A. Architektura kontekstut; monografia Architek-
tura $1 / 2014$ Publisher: Politechnika Swiętokrzyska, Kielce [8] Seruga W. Eksperymenty i poszukiwania w ksztaltowaniu wspotczesnych przestrzeni miasta lin: A Architektur
Kielc. Teraziniejzzość i i erspekttwa jutra; chapter in the mo-
nograph Architektura 8, p. 189-204, Publisher: Politechnika Swietokrzyska, Kielce 2019
99 Seruga W. Harmonia w tektura zharmonizowana $w$ przestzstrenini miejskista; [in: chapter in the monograph Architektura 4, p.9.9-20, Publisher: Politech-
nika Swiettokrzyska, Kielce 2016 [10] Stachura E., Śodowisko mieszkaniowe w Polsce. Oce-
na, oczekiwania, aspiracje; Publisher; Politechnika Krakow-
ska, Kraków 2013 


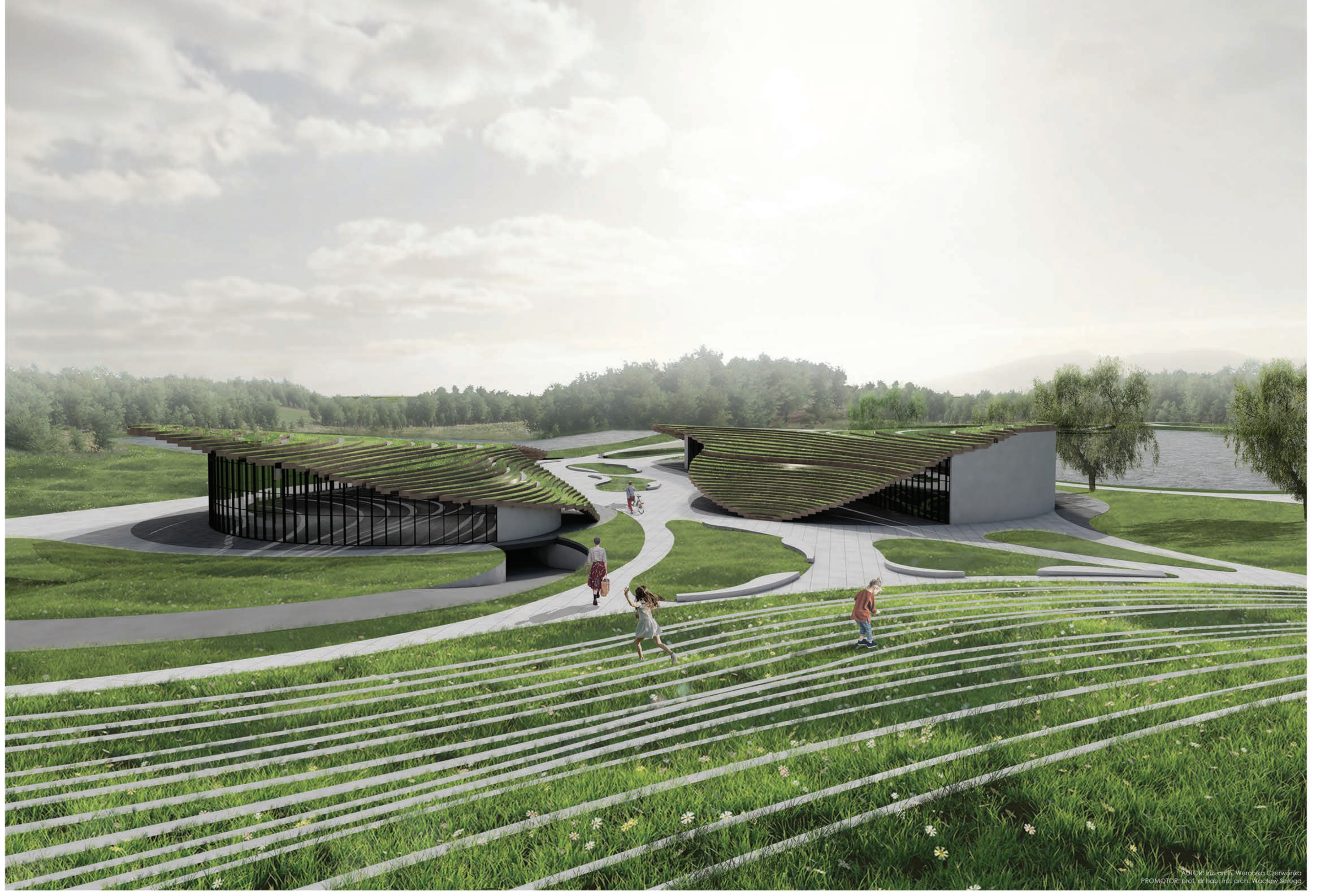



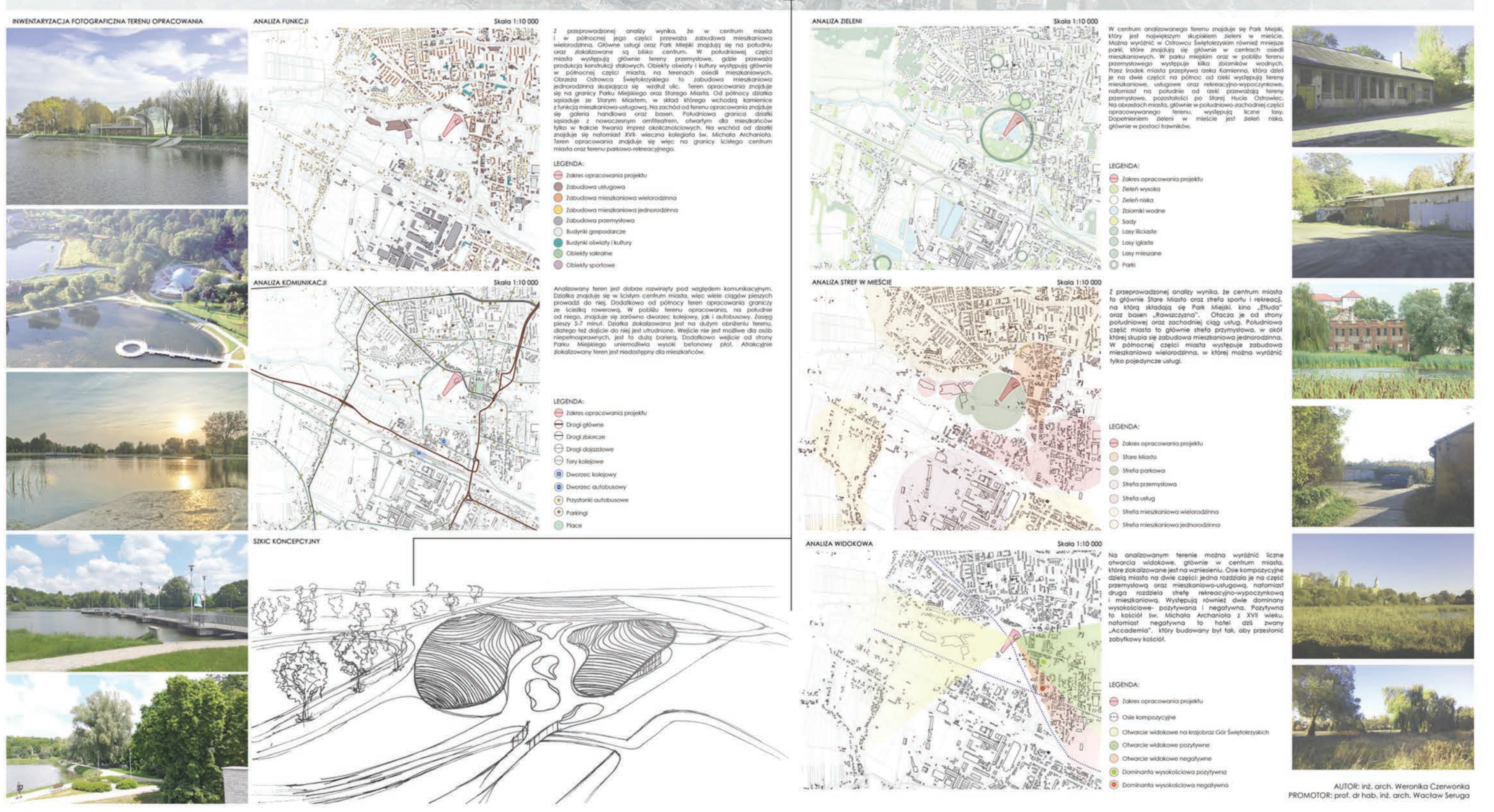

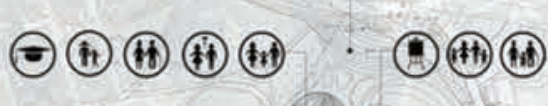

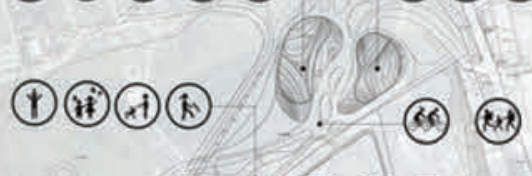

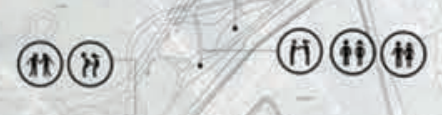




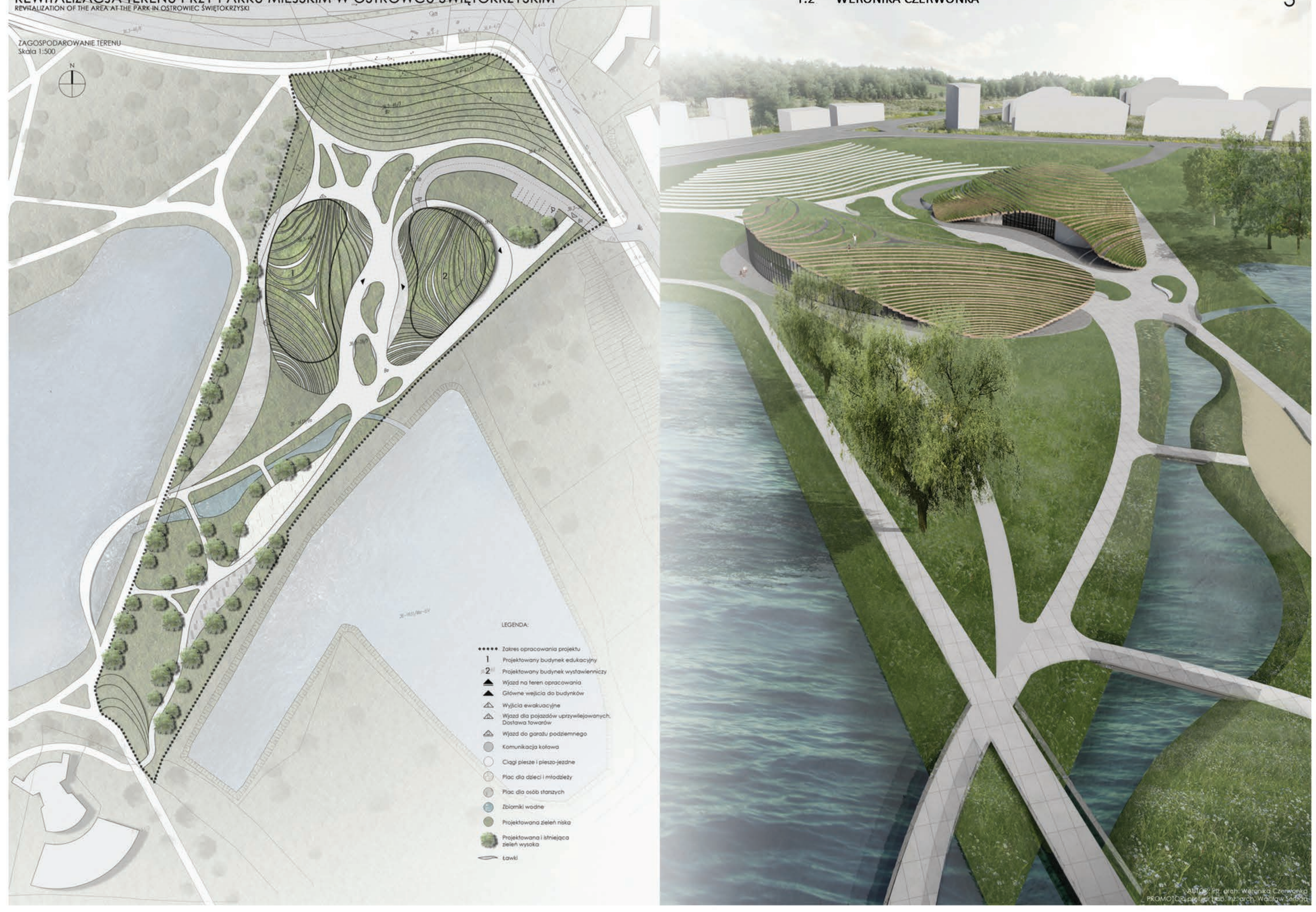




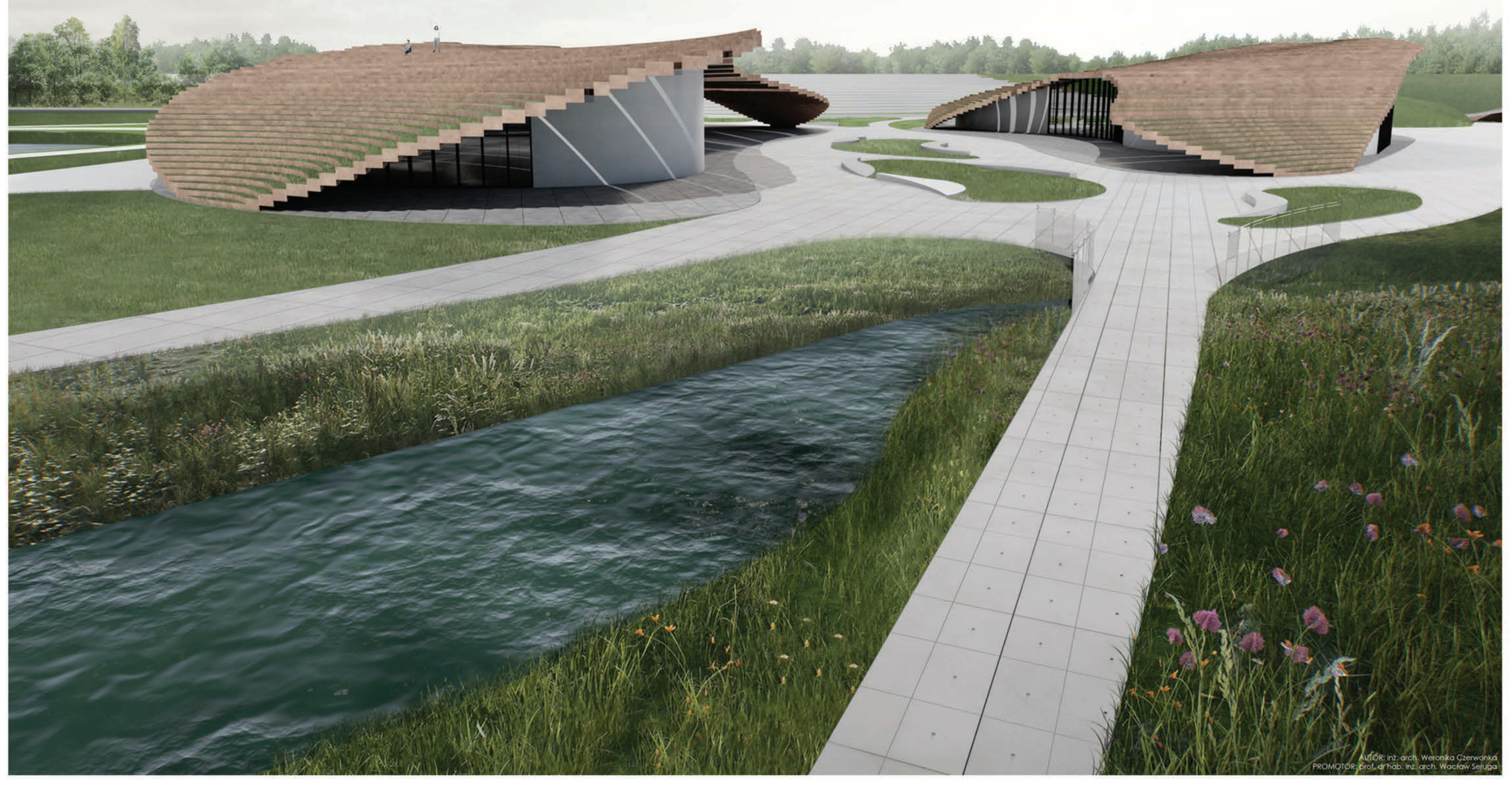




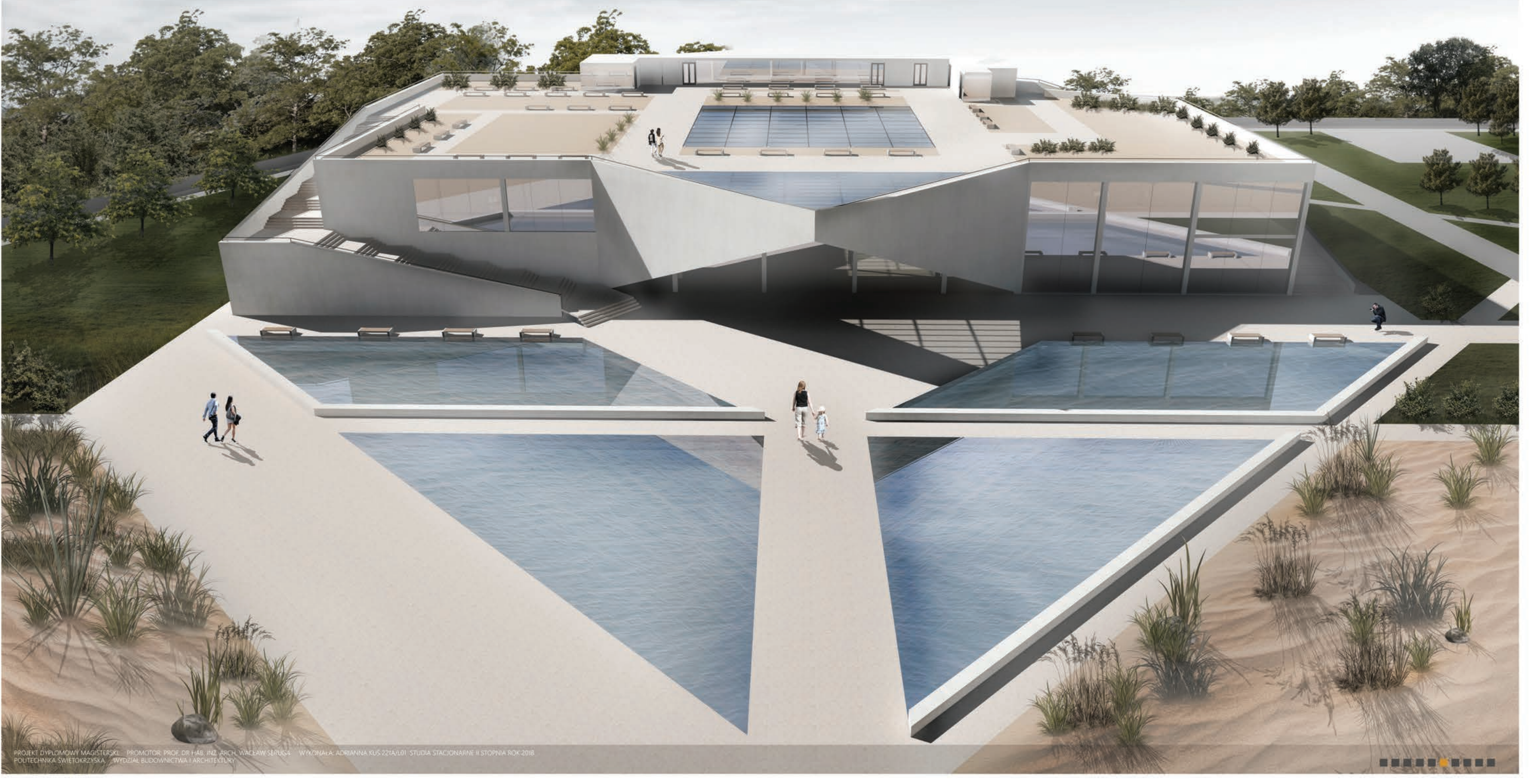




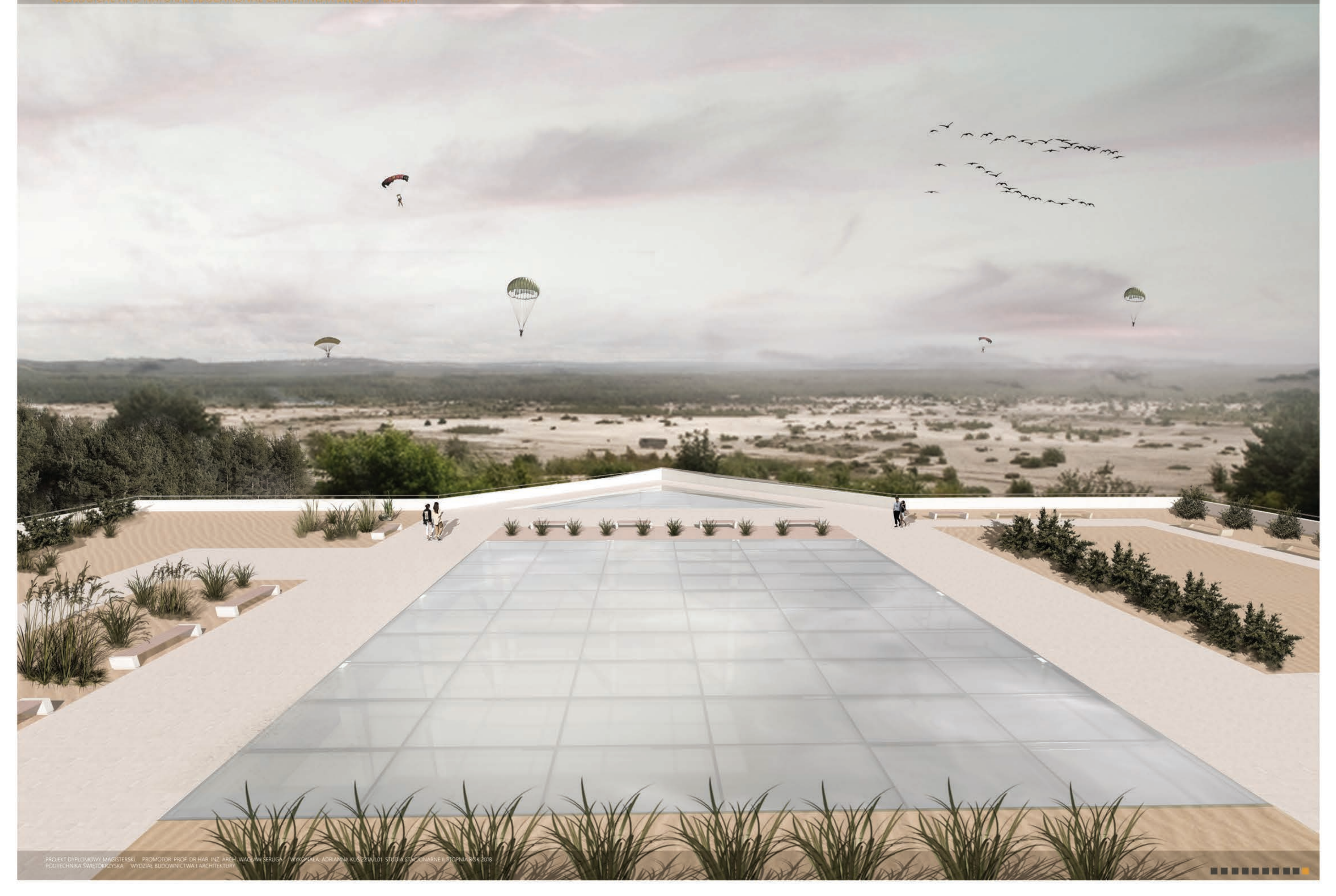


ŚWIĘTOKRZYSKIE CENTRUM NAUKI
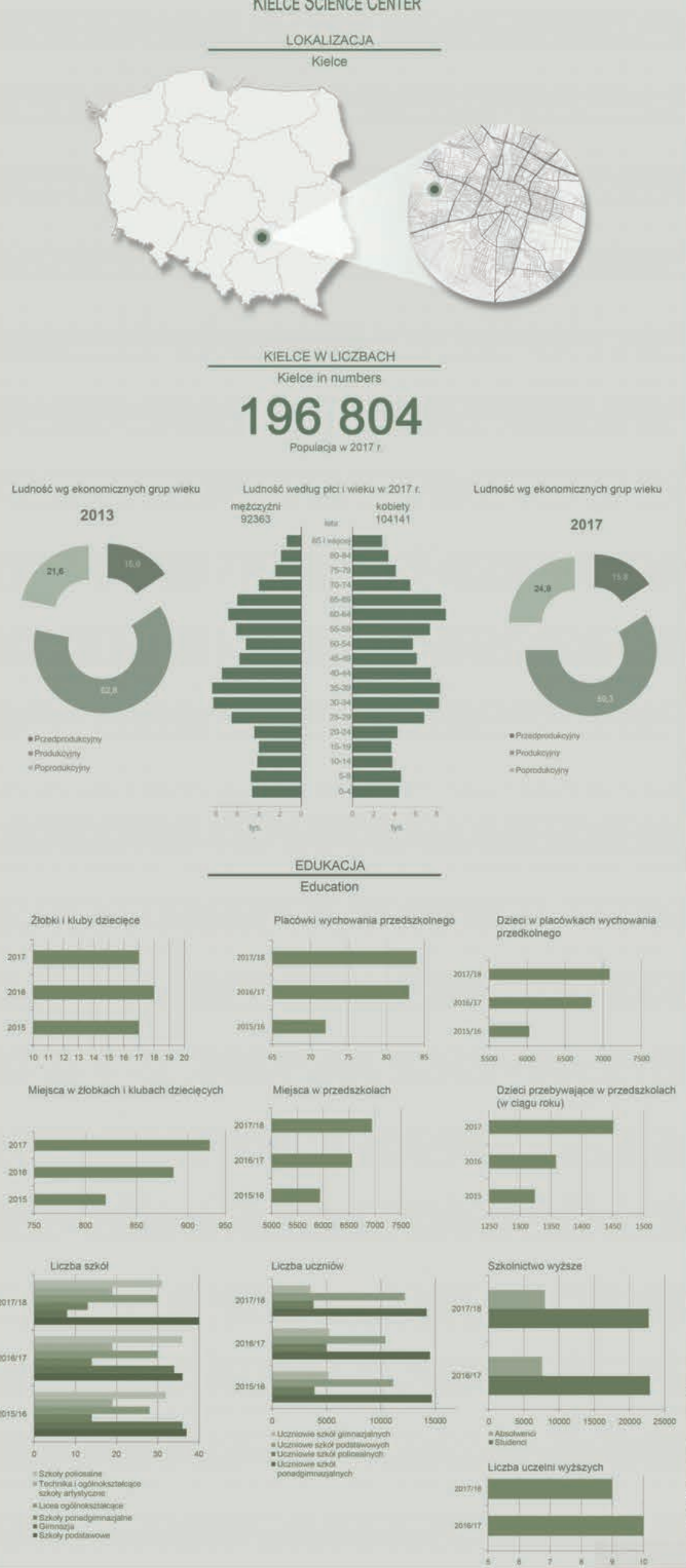

P.8 EWELINA METRYCKA

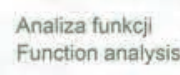

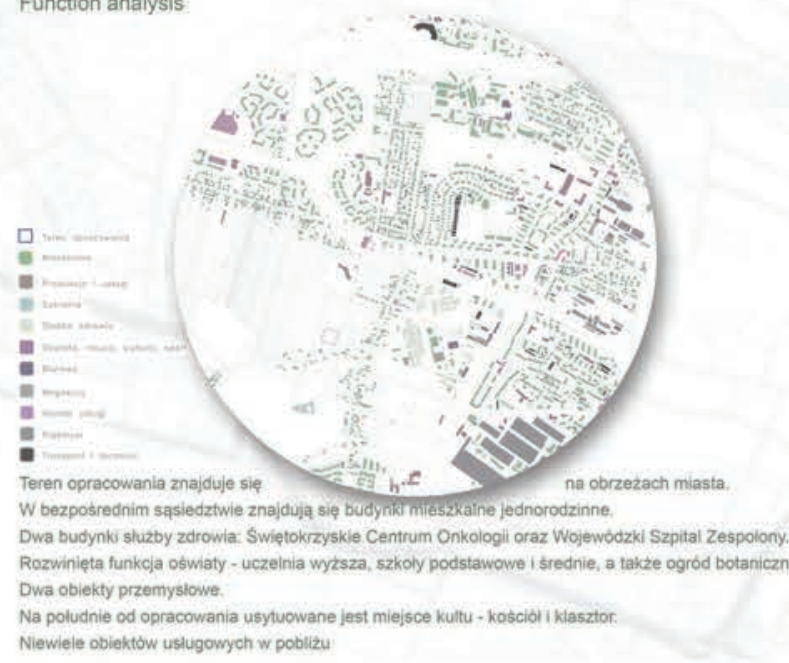

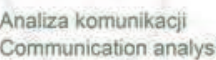

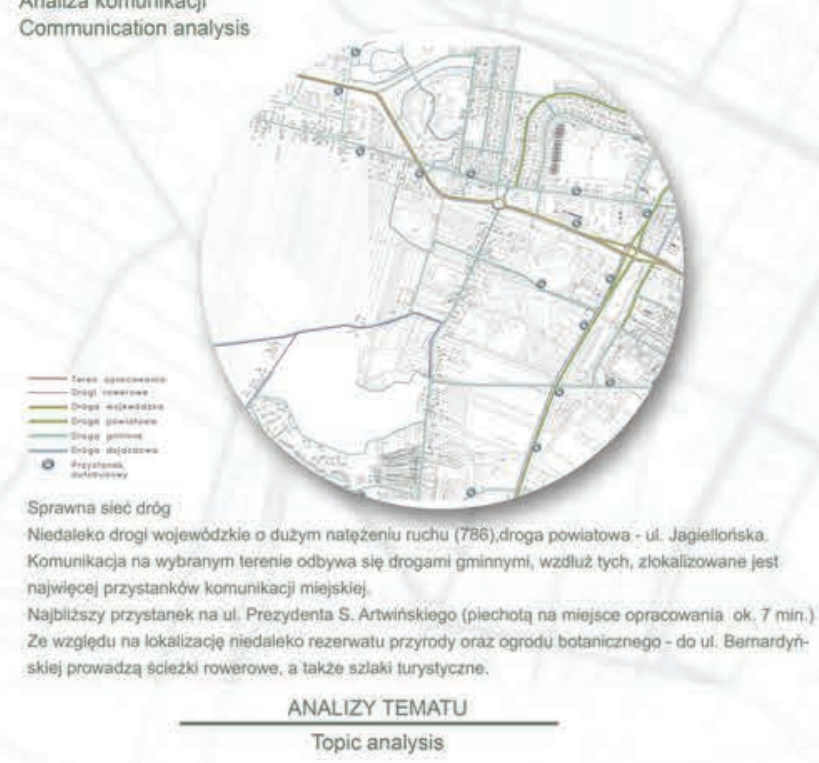

Anaiza widokow
View analysis

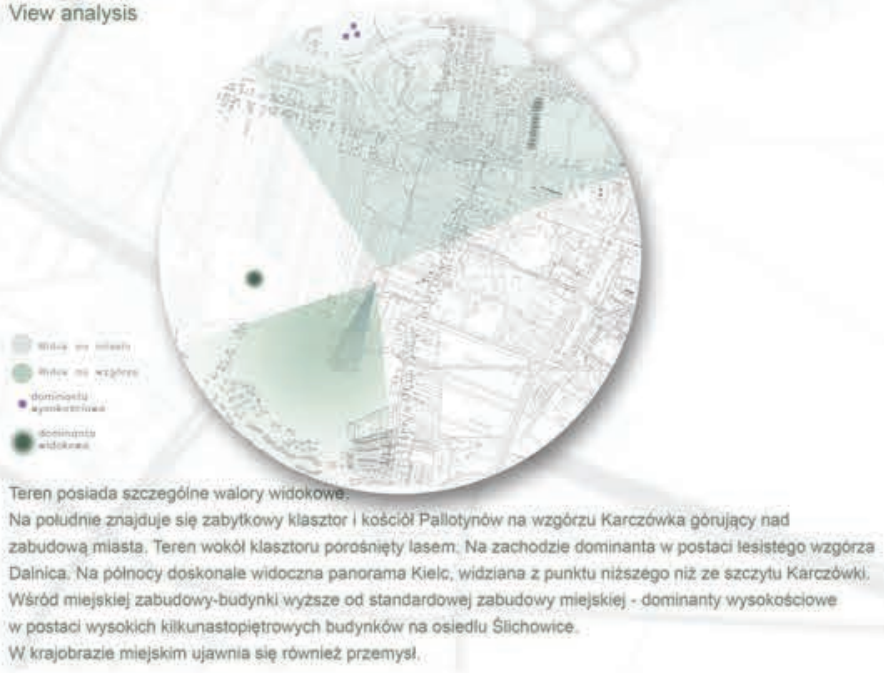

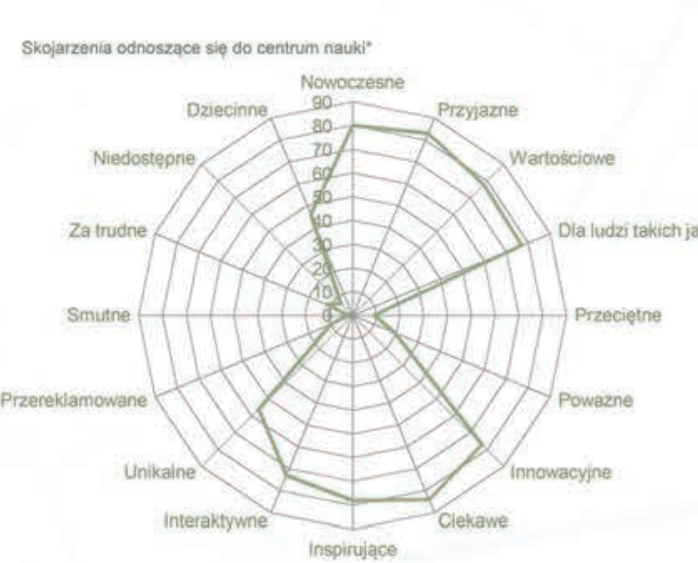

inspiviuace

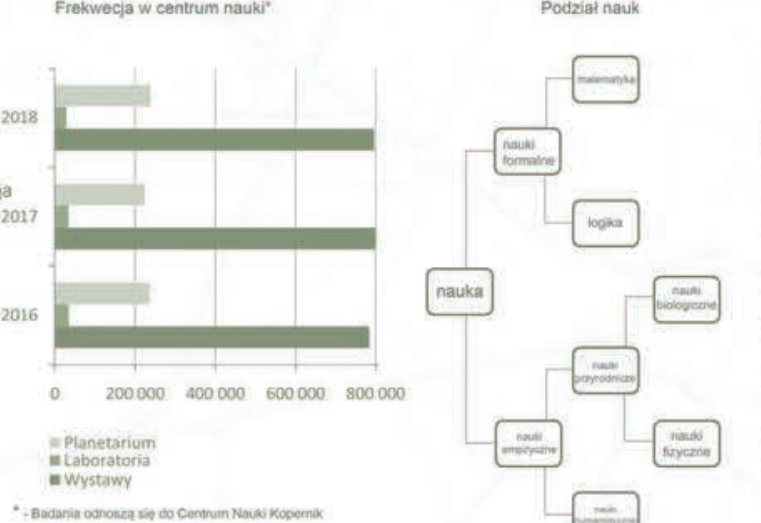

$\theta$
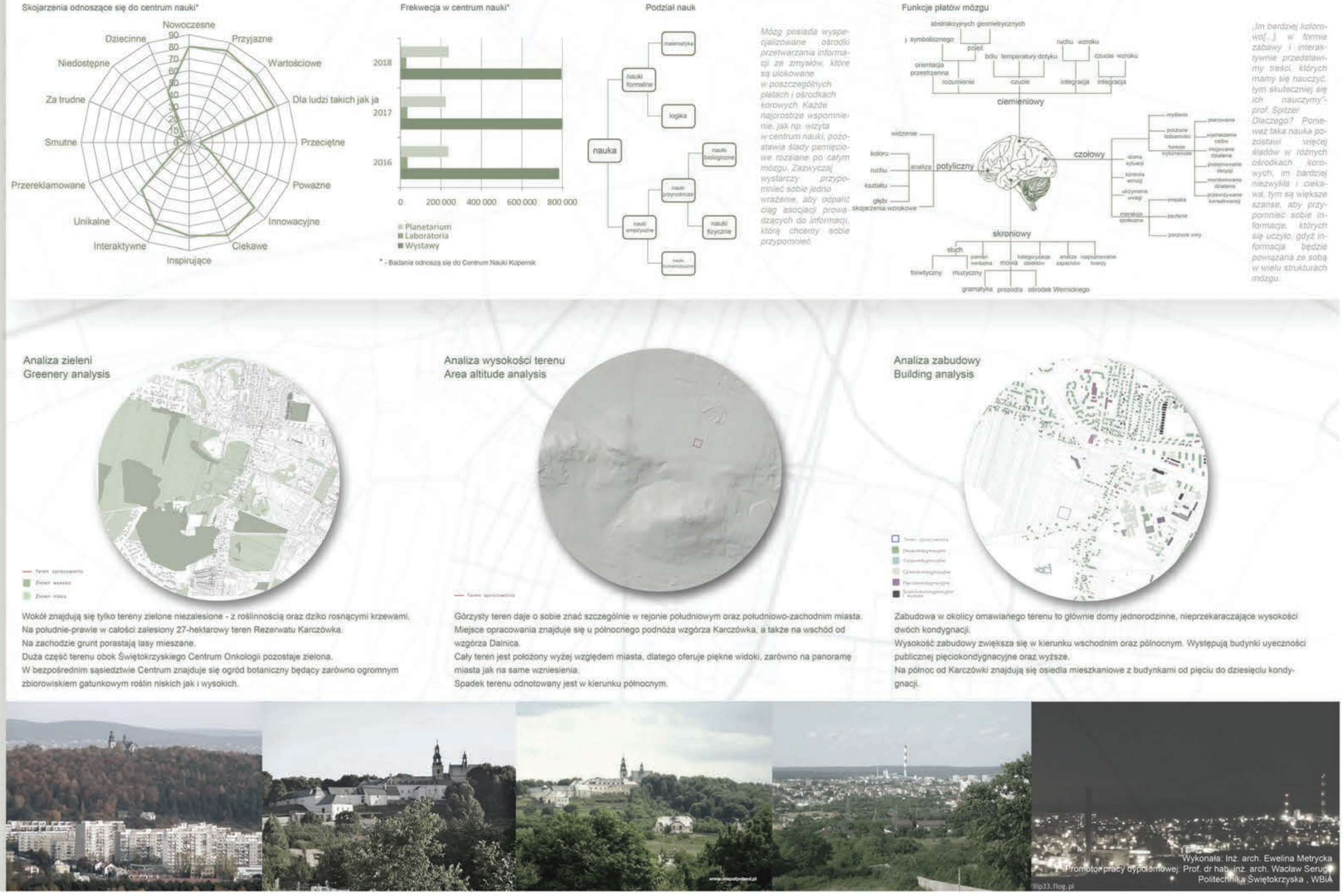


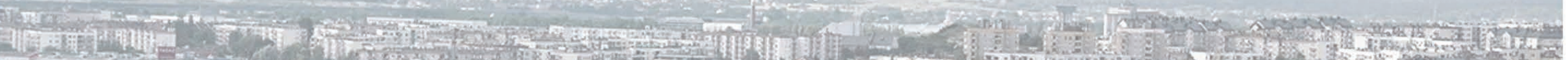

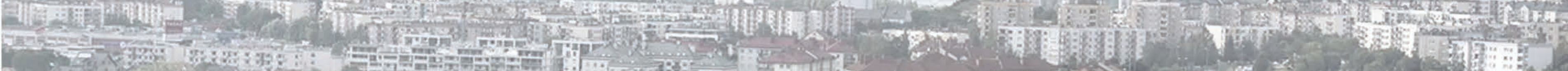

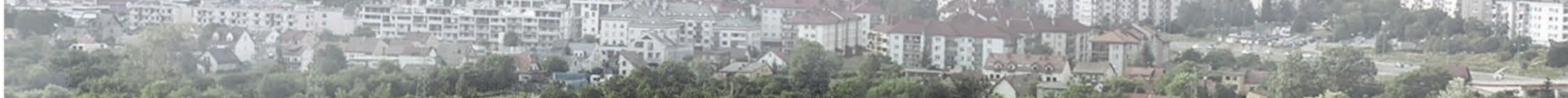

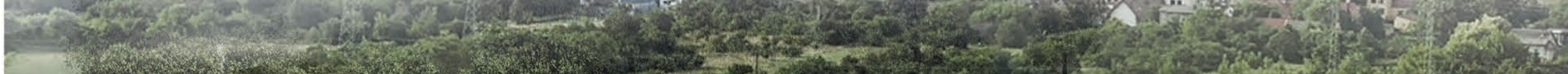

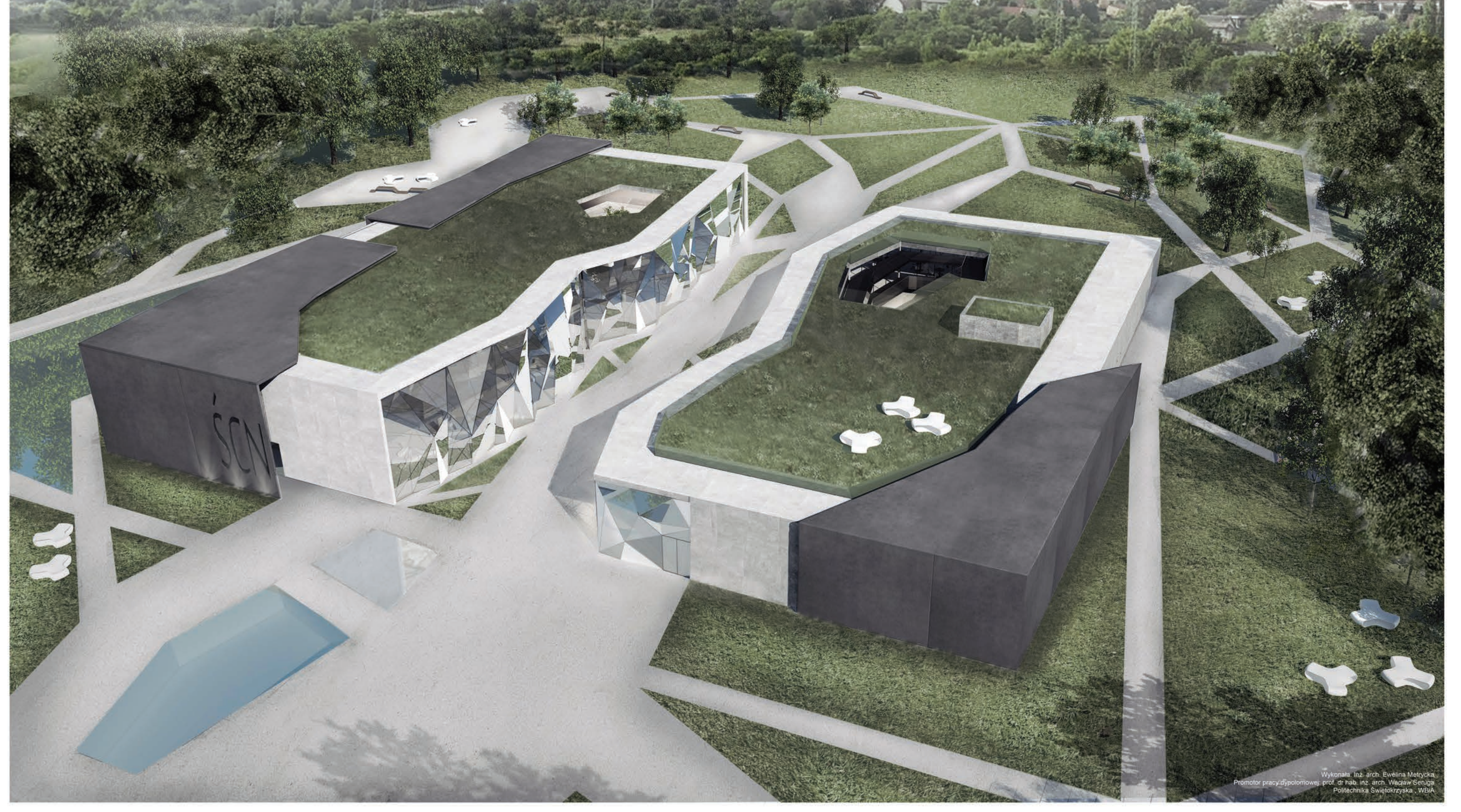


ŚWIĘTOKRZYSKIE CENTRUM NAUKI P.10 EWELNA METRYCKA KEECE SOEECEE CENTER

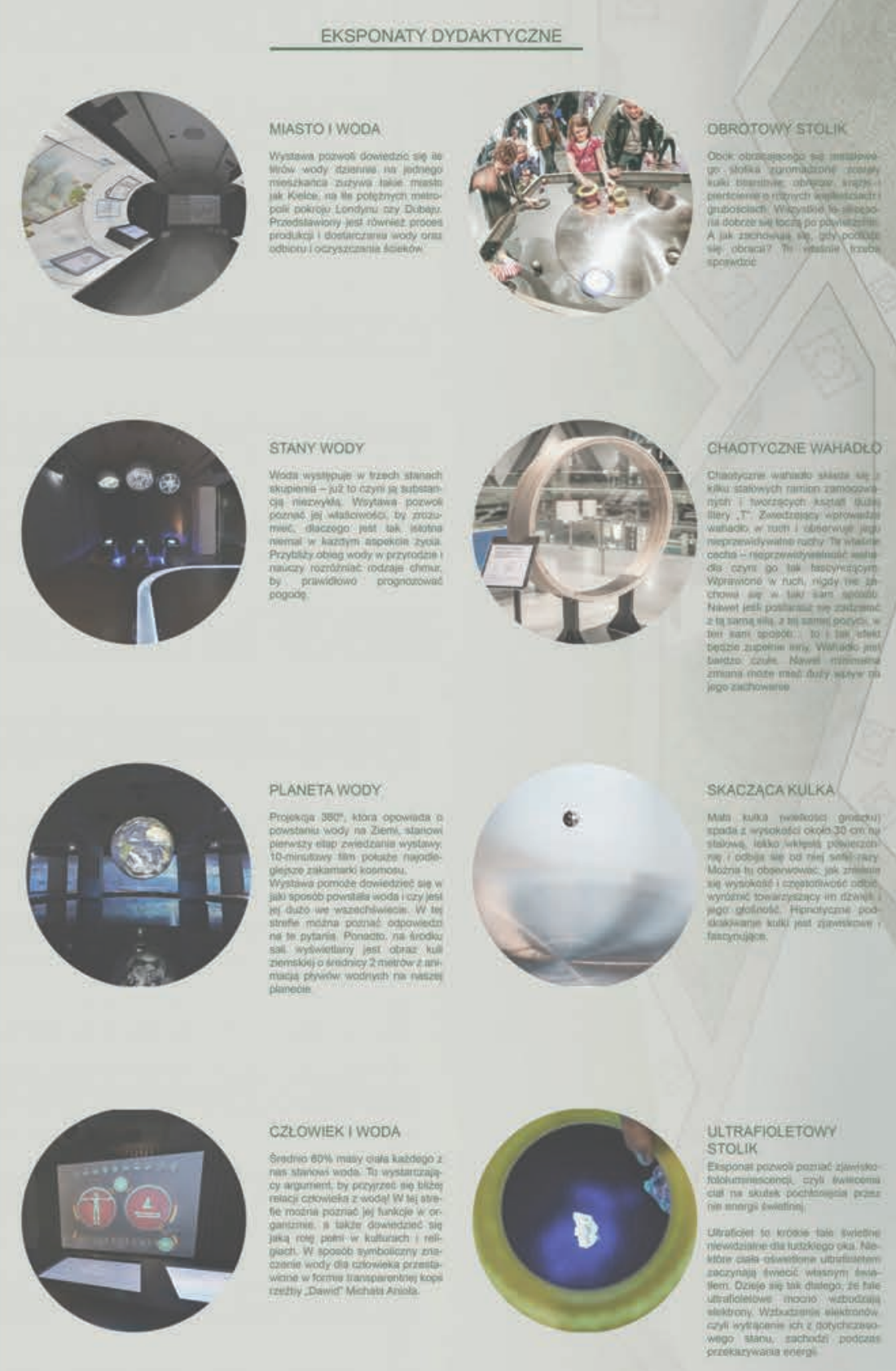

SYSTEM ZAGOSPODAROWANIA WODY OPADOWEJ

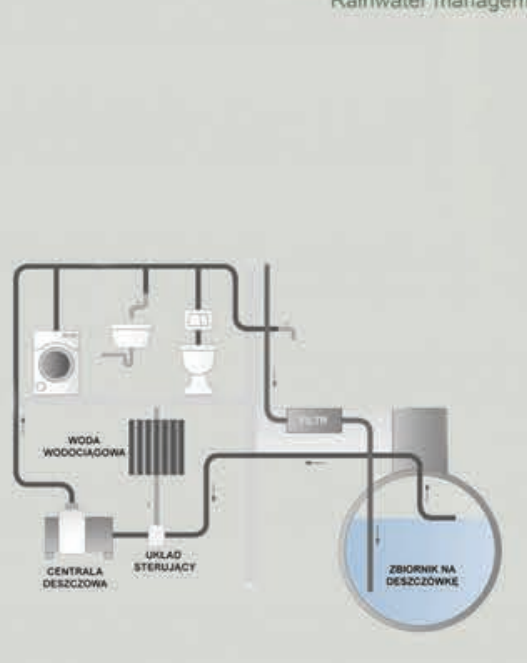
Section C.C 1:200
¿
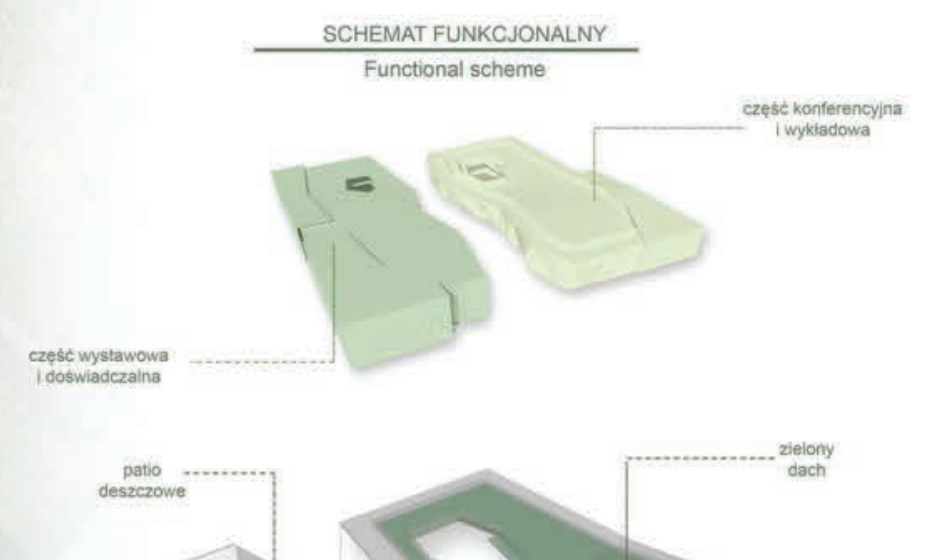

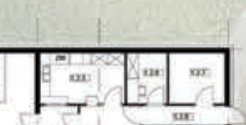
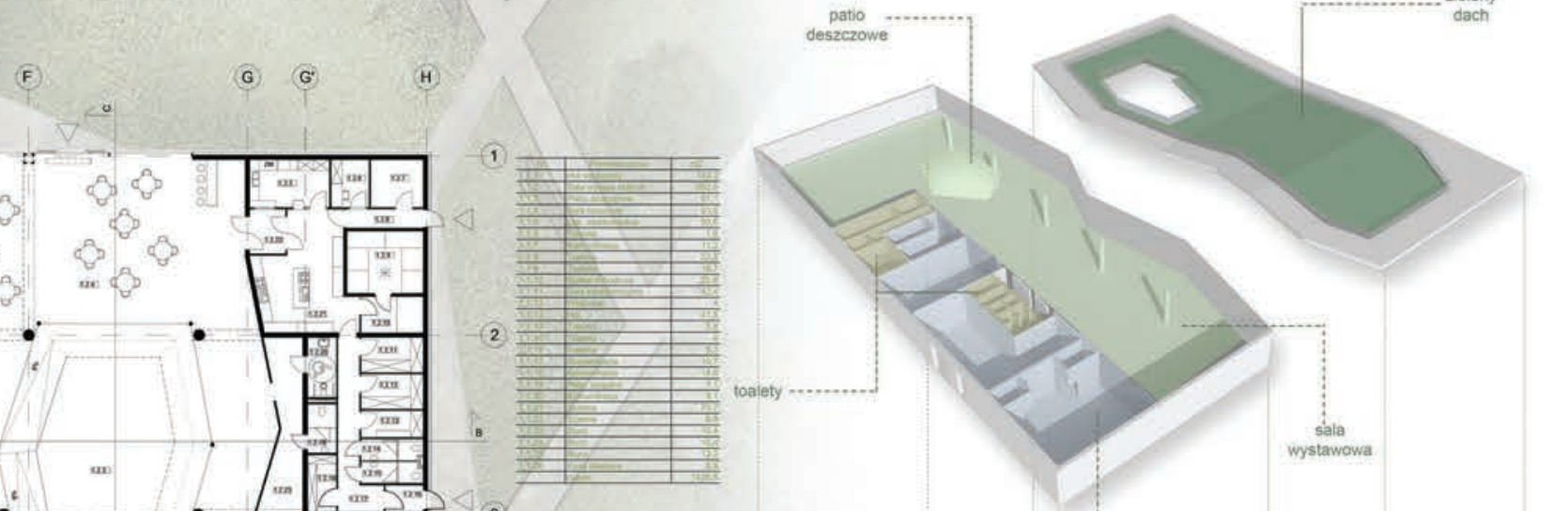
-
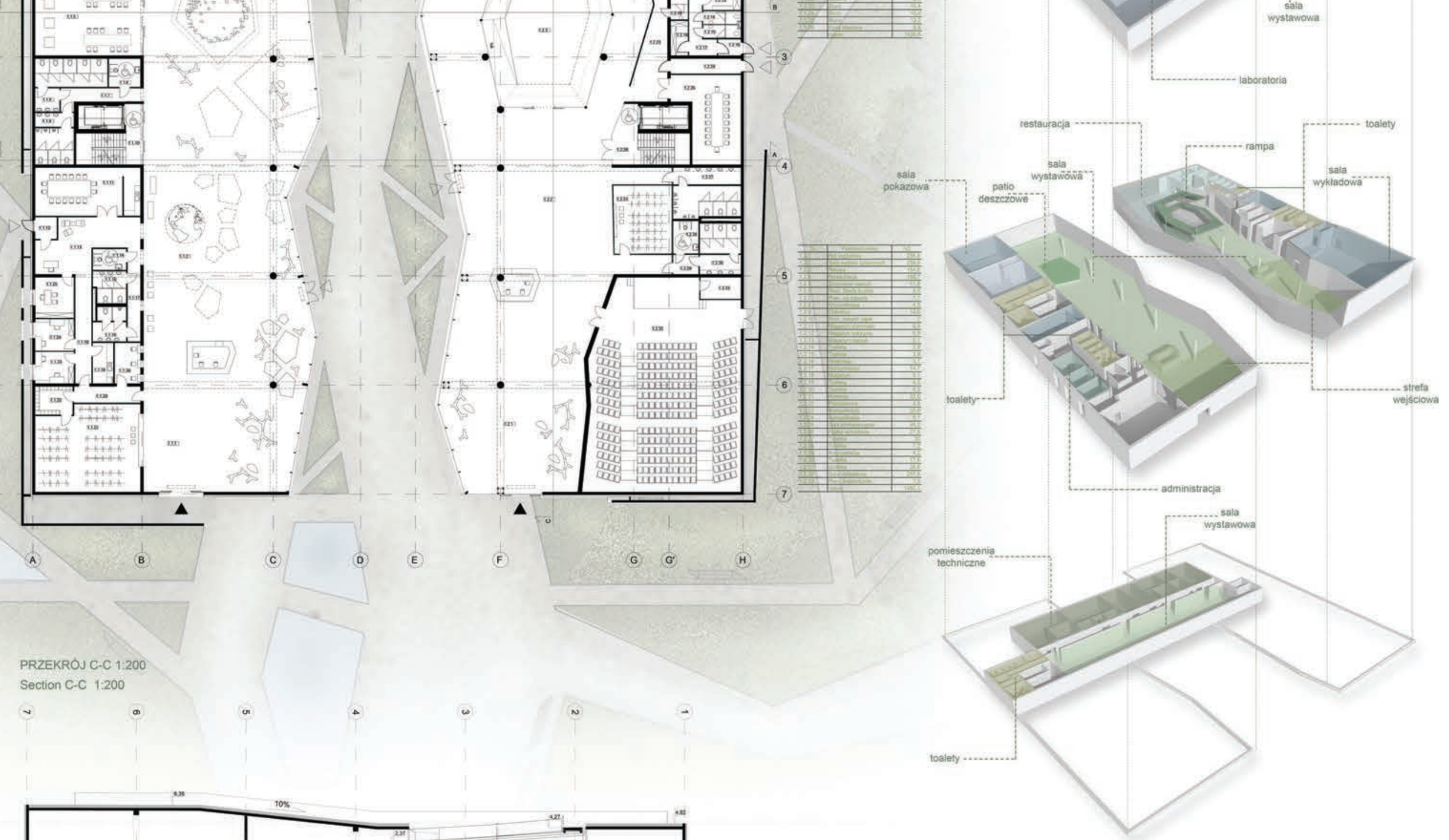

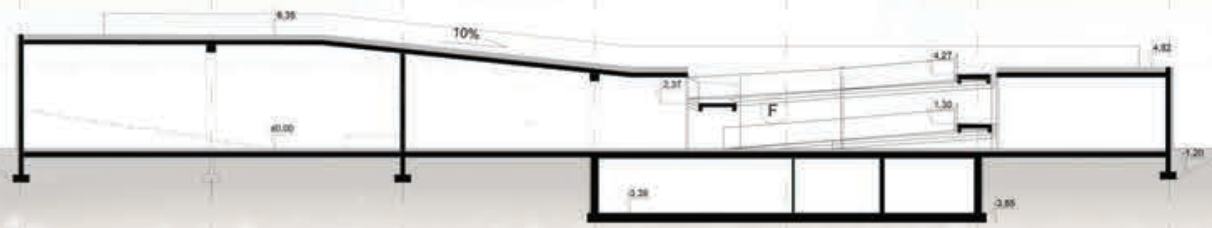




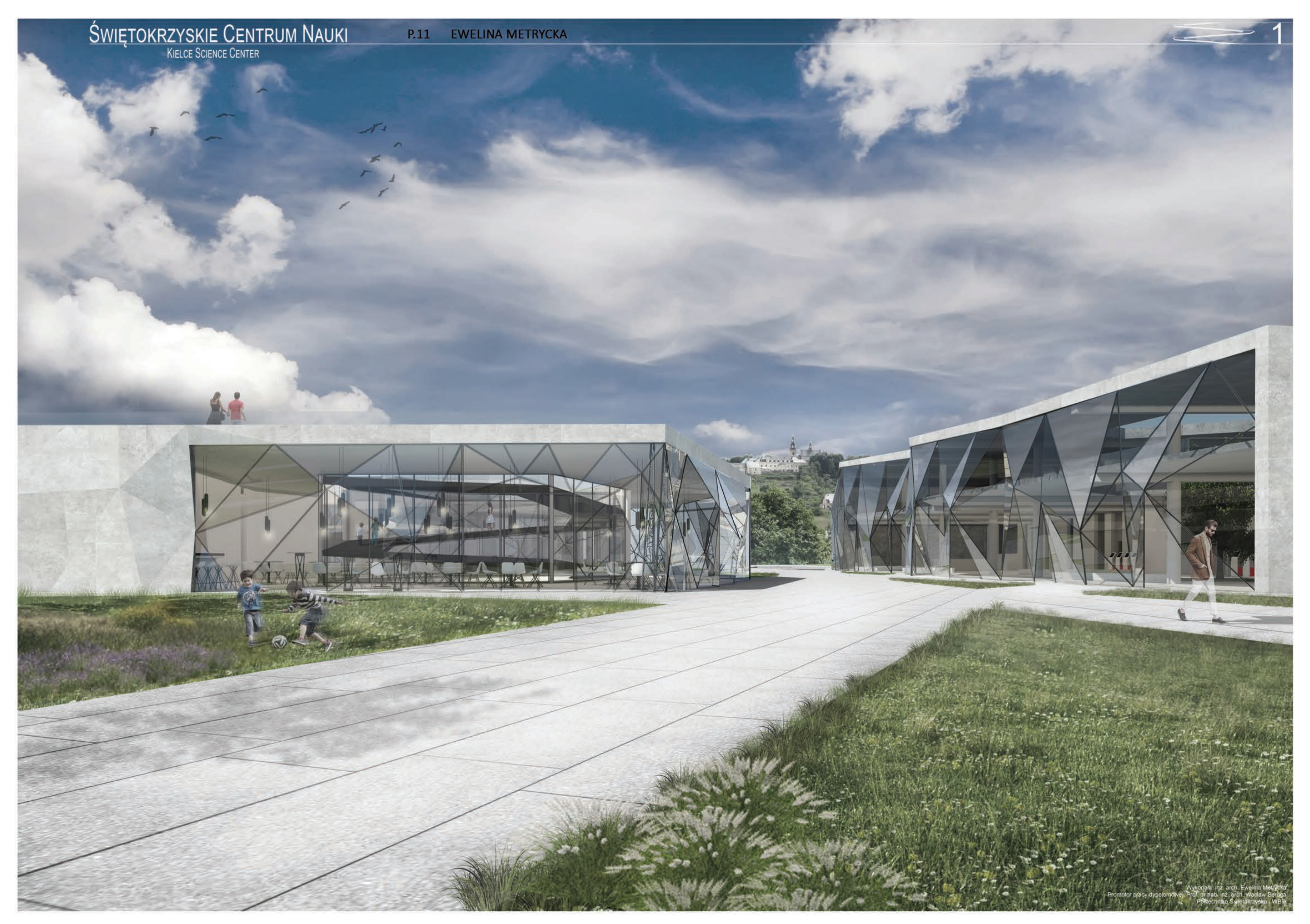



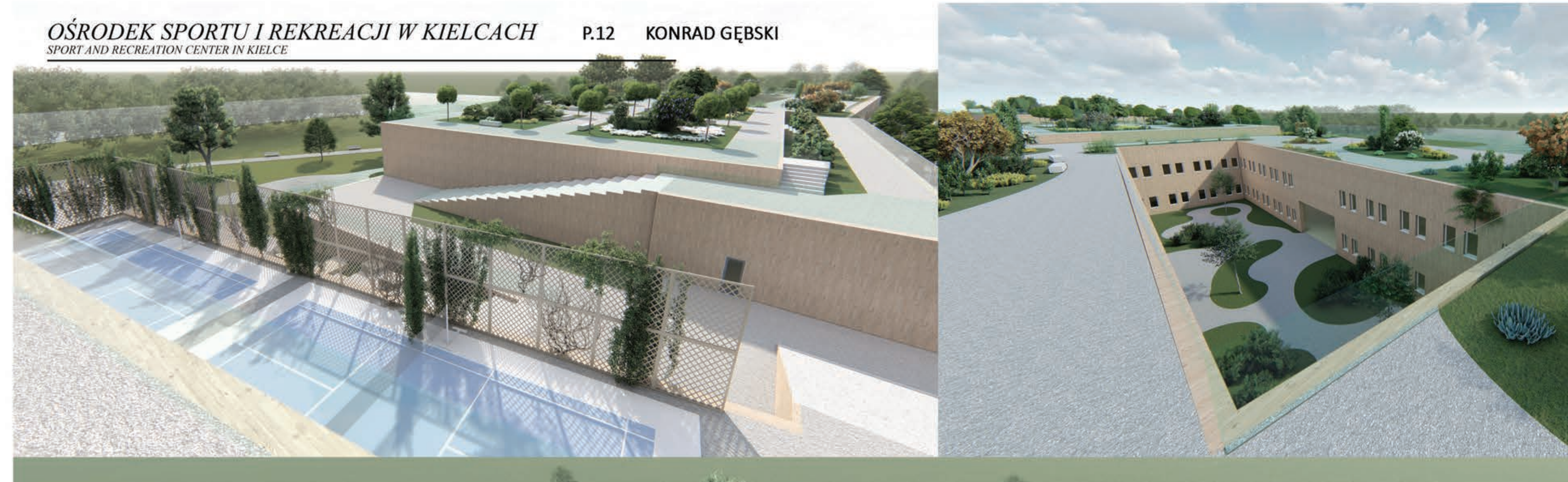

25
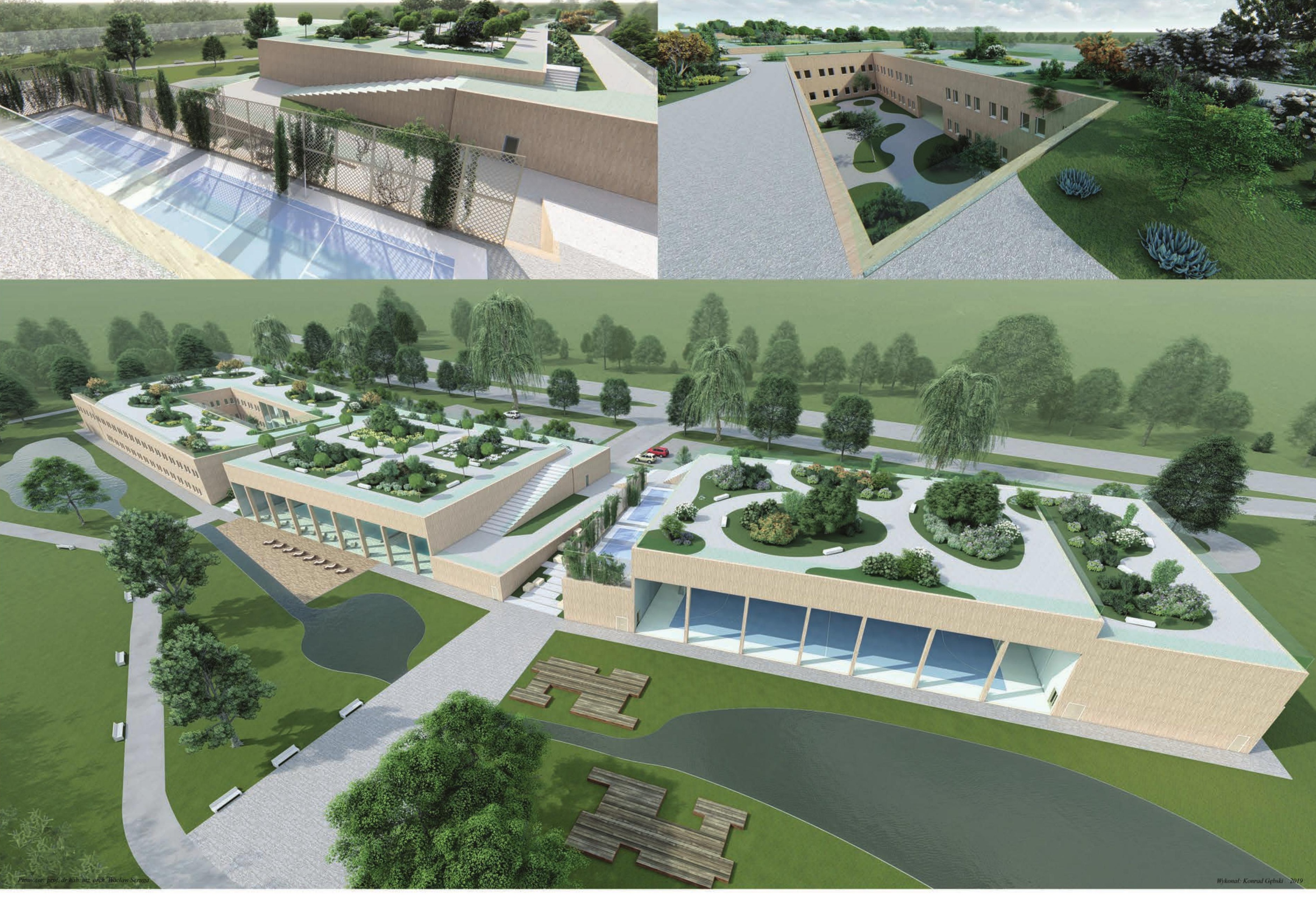


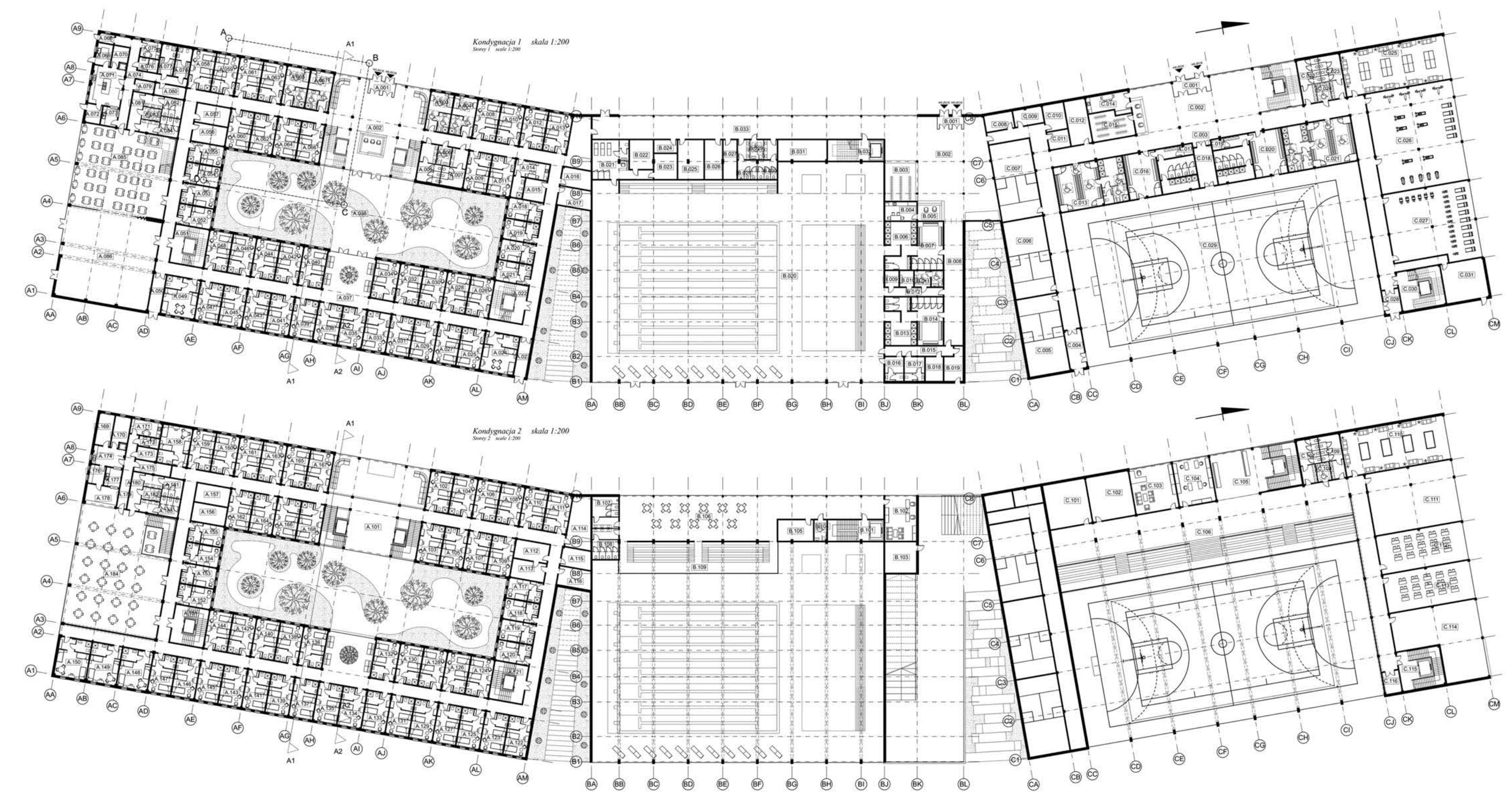




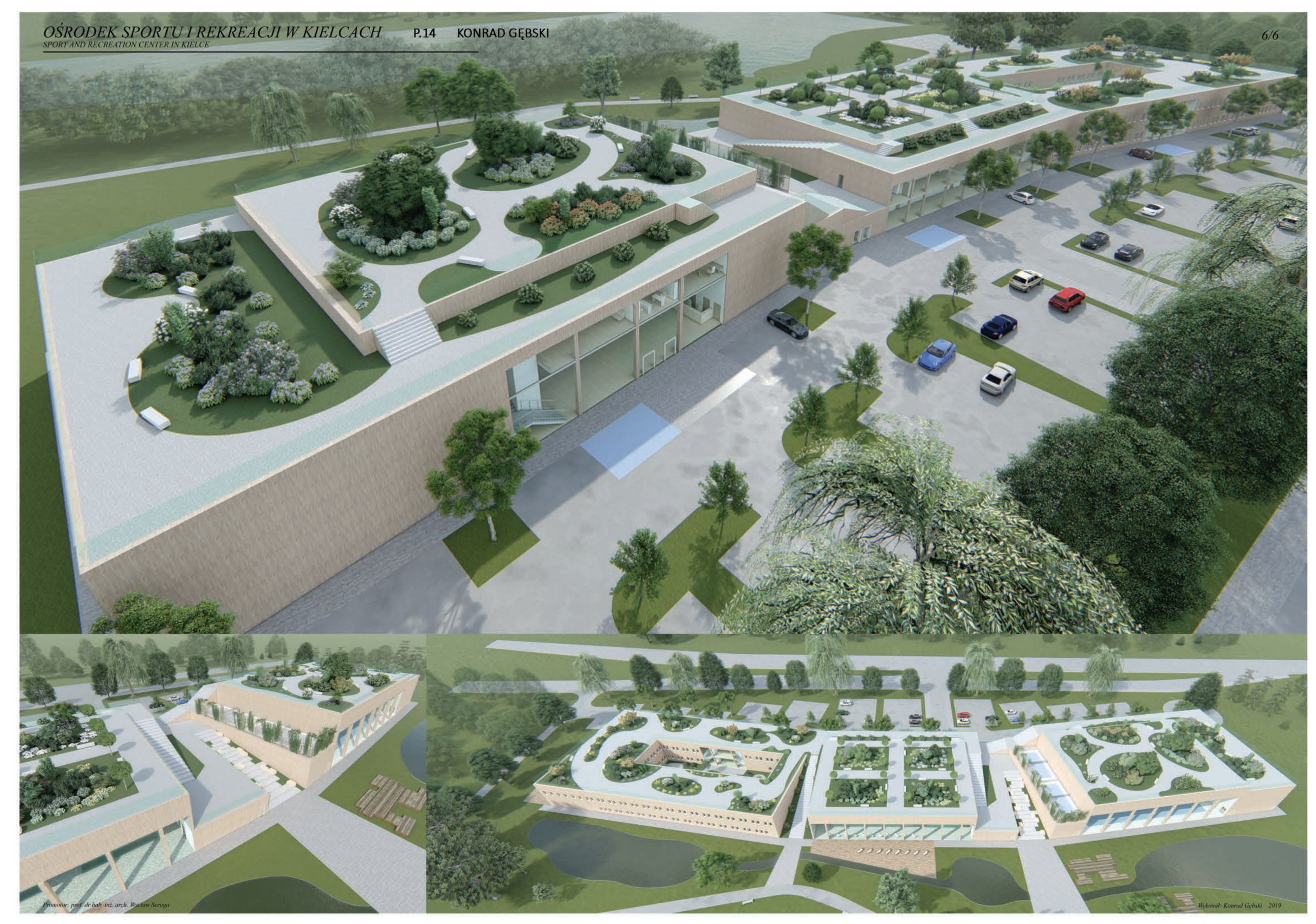

